\title{
Structural Effects on Adsorption of Atmospheric Gases in Mixed Li,Ag-X-Zeolite
}

\author{
Nick D. Hutson and Ralph T. Yang \\ Dept. of Chemical Engineering, U niversity of M ichigan, Ann A rbor, MI 48109
}

\begin{abstract}
Silver is known to strongly affect the adsorptive properties of zeolites. In the synthesis of mixed Li,Ag low-silica X-type (LSX) zeolite, adding very small amounts of silver and specific dehydration conditions results in a sorbent with enhanced adsorptive characteristics for air separation. The location of the extraframework silver in relation to the aluminosilicate framework is of primary importance for elucidating the effect of silver cations on the adsorptive characteristics of the zeolite. In this work, mixed Li,Ag ion-exchanged zeolites were synthesized and treated to promote the formation of intracrystalline silver clusters. These samples were structurally characterized using Rietveld refinement of neutron powder diffraction data. Structural characterization revealed the presence of cations in a novel site II* in mixed Li,Ag- LSX zeolites that were vacuumdehydrated at $450^{\circ} \mathrm{C}$. Cations in this site $1{ }^{*}$ are more interactive with the atmospheric sorbates of interest than silver at the conventional site II location. Vacuum dehydration at $450^{\circ} \mathrm{C}$ induced thermal migration of $\mathrm{Ag}^{+}$from site II to site $\mathrm{II}^{*}$ and gives rise to the superior properties for air separation.
\end{abstract}

\section{Introduction}

The separation of air for the production of nitrogen and oxygen is an important operation in the chemical processing industry. $\mathrm{H}$ istorically, this separation has been done by cryogenic distillation. As adsorption systems have become more efficient and new, more effective sorbents have been synthesized, separation by adsorption processes [such as pressure swing adsorption (PSA), and vacuum swing adsorption (VSA )] have become increasingly competitive and are already favorable for small-to-medium-scale operations ( $Y$ ang, 1997). Currently, approximately $20 \%$ of air separations are accomplished using adsorption technologies (R ege and $Y$ ang, 1997).

While it has long been known that $\mathrm{Li}^{+}$is among the strongest cations, with respect to its interaction with $\mathrm{N}_{2}$ (M c$\mathrm{Kee}, 1964)$, its use was greatly increased with two recent advances. First, it was found that $\mathrm{Li}^{+}$ion-exchange in $\mathrm{X}$-type zeolite must exceed an approximate $70 \%$ threshold before the $\mathrm{Li}^{+}$has any effect on the adsorptive properties of the material (Chao, 1989; Chao et al., 1992; Coe et al., 1992; Coe,

Correspondence concerning this article should be addressed to R. T. Y ang.
1995). Secondly, a significant increase in the $N_{2}$ adsorption capacity was seen in $\mathrm{Li}^{+}$ion-exchanged low-silica X (LSX) zeolite over that of the typical commercial material ( $\mathrm{Si} / \mathrm{Al} \approx$ 1.25). Because of these advances, $L i-L S X$ is now the best sorbent in industrial use for the separation of air by adsorption processes (R ege and $Y$ ang, 1997).

Examples of mixed-cation zeolites have also been given. Coe et al. (1992) reported the use of a binary exchanged Xzeolite having lithium and calcium and/or lithium and strontium ions in a ratio of $5 \%$ to $50 \%$ calcium and/or strontium and $50 \%$ to $95 \%$ lithium. This material provided for enhanced nitrogen adsorption over those of the $\mathrm{Na}-\mathrm{X}, \mathrm{Li}-\mathrm{X}$, and $\mathrm{Ca}-\mathrm{X}$ zeolites. Chao et al. (1992) showed the use of mixed ion-exchanged $A$ and $X$ zeolites with lithium and an alkaline earth metal (such as $\mathrm{Ca}^{2+}, \mathrm{Sr}^{2+}$ ). In this case, the zeolite contained lithium and the alkaline earth cations in a mixture of $10 \%$ to $70 \%$ alkaline earth and $30 \%$ to $90 \%$ lithium. These mixed cation zeolites provided high adsorption capacity and high thermal stability. Fitch et al. (1995) reported good $\mathrm{N}_{2} / \mathrm{O}_{2}$ selectivity and $\mathrm{N}_{2}$ capacity with mixed $\mathrm{Li}_{x} \mathrm{~A} \mathrm{I}_{y}-\mathrm{X}$ zeolite (that 
is, using $\mathrm{Al}^{3+}$ as the nonframework charge-compensating cation).

Silver is also known to have very strong effects on the adsorption characteristics of zeolites (H abgood, 1964; H uang, 1974; Hutson et al., 2000). Y ang et al. (1996) reported the synthesis of a mixed lithium-silver $(80 / 20)$ ion-exchanged $X$ type zeolite $\left(\mathrm{Si} / \mathrm{Al} \approx 1.25\right.$, with approximately $17 \mathrm{Ag}^{+}$per unit cell), and discussed its potential use in air separation. This sorbent utilized the very strong adsorptive properties of the $\mathrm{Ag}^{+}$ion that provided for increased capacity over that of the $\mathrm{L}-\mathrm{X}$ while maintaining some degree of the advantageous isotherm linearity that is seen with $\mathrm{L}-\mathrm{X}$. Ab initio molecular orbital calculations showed that the adsorption of nitrogen was enhanced by weak chemical interaction (through a classic $\pi$-complexation bond) with the $\mathrm{Ag}^{+}$cation on the zeolite framework (Chen and $Y$ ang, 1996).

Hutson et al. (1999) have reported the synthesis of mixed Li,A g low-silica $X$-type zeolite in which the addition of very small amounts of silver and specific dehydration conditions resulted in enhanced adsorptive characteristics and increased energetic heterogeneity relative to those of the fully (or near fully) exchanged $\mathrm{Li}^{+}$zeolites. The performance of air separation by the best of these sorbents, containing, on average, only one A g cation per unit cell, was compared to that of the fully (or near fully) $\mathrm{Li}^{+}$-exchanged zeolite using a standard pressure-swing adsorption (PSA) cycle by numerical simulation. The results showed that the new sorbent provides a significantly higher $(>10 \%)$ product throughput at the same product purity and recovery, when compared to that of the fully $\mathrm{Li}^{+}$-exchanged zeolite ( $\mathrm{Y}$ ang and Hutson, 1999).

The location of the extraframework silver in relation to the aluminosilicate framework is of primary importance for elucidating the effect of silver cations or clusters on the adsorptive characteristics of the zeolite. In this work, we have synthesized mixed $\mathrm{Li}, \mathrm{Ag}$ ion-exchanged zeolites and treated these materials in ways that promote the formation of intracrystalline silver clusters. These samples were structurally characterized using Rietveld refinement of neutron powder diffraction data. The structural data were then related to the adsorptive characteristics of the mixed-cation zeolites for the gases that are of primary interest in the separation of air: $\mathrm{N}_{2}$ $\mathrm{O}_{2}$, and $\mathrm{Ar}$.

\section{Synthesis and Analysis}

Two type- $X$ zeolites, differing only by the $\mathrm{Si} / \mathrm{A}$ I ratio, were used in this work. These were: (1) X-type zeolite with a Si/A I of 1.0 (Praxair, \#16193-42, sometimes referred to as LSX, low-silica X-zeolite), and (2) X-type zeolite with a Si/AI of 1.25 (Linde, lot 945084060002). B oth of these materials were binderless, hydrated powders. The unit cell for faujasite zeolites ( $Y, X, L S X)$, including conventional designation of cation sites, is shown in Figure 1.

Since the sodium form of the zeolite exchanges more readily with most cations in consideration, all zeolites were first ion-exchanged with a solution of sodium chloride in order to convert to the $\mathrm{Na}^{+}$form. A dilute $\mathrm{NaOH}$ solution was used to keep the $\mathrm{NaCl}$ solution at $\mathrm{pH} \approx 9$. This helps to prevent hydrolysis and breakdown of the zeolite crystal structure during the ion-exchange process. The resultant $\mathrm{Na}^{+}$-zeolite was then used as the starting material for subsequent syntheses.

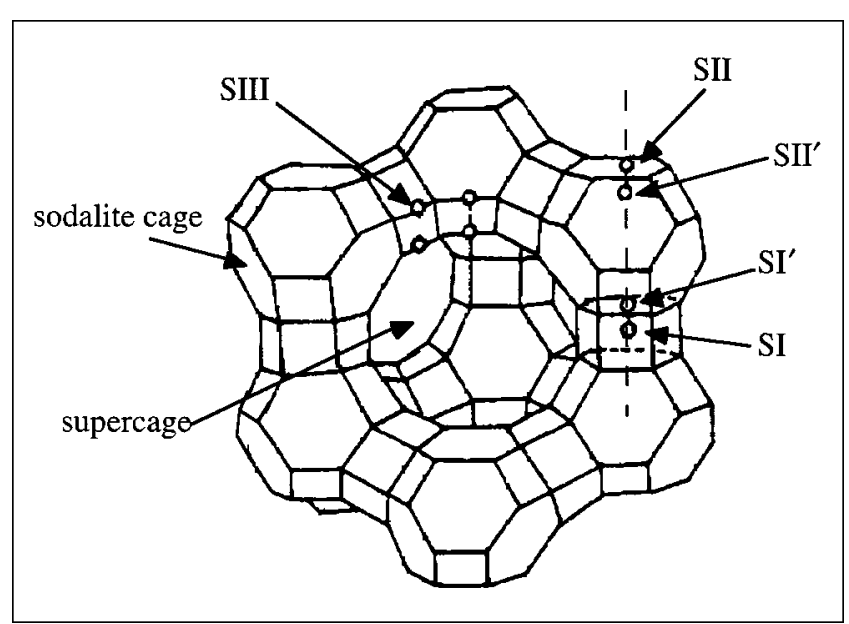

Figure 1. Unit cell, including cation sites, for faujasite zeolites.

The lithium zeolites were prepared by five consecutive static ion-exchanges using a 6.3-fold excess (over that necessary for full ion exchange) of a $2.2 \mathrm{M}$ solution of $\mathrm{LiCl}$. This was done in a $0.01-\mathrm{M}$ solution of $\mathrm{LiOH}$ at a $\mathrm{pH} \approx 9$. The lithium ion-exchange solution was heated to a mild boil and then allowed to cool and settle. The solution was decanted, a fresh $6.3 \mathrm{X} \mathrm{LiCl}$ solution was added, and the procedure was repeated for a total of five exchanges. A fter the final ion exchange, the material was vacuum filtered and washed with copious amounts of deionized water until no free ions were present in the filter water (that is, no $\mathrm{AgCl}$ precipitation upon treatment with $\mathrm{Ag}^{+}$). The resulting lithium exchanged zeolites were dried overnight at $100^{\circ} \mathrm{C}$ in a conventional oven before being dehydrated in vacuo prior to measurement of adsorption isotherms.

The silver zeolites were prepared by two consecutive ion exchanges using a $0.05-\mathrm{M}$ solution of $\mathrm{AgNO}_{3}$. E ach silver solution contained a cation content that was double that required for $100 \%$ exchange. The silver ion-exchange solution was heated to a mild boil and immediately allowed to cool and settle. As with the lithium ion-exchange, the solution was decanted, fresh $\mathrm{AgNO}_{3}$ solution was added, and the procedure was repeated for a total of two exchanges. A fter the second ion exchange, the material was vacuum filtered and washed with copious amounts of deionized water until no free ions were present in the filter water (that is, no precipitation upon treatment with $\mathrm{Cl}^{-}$). The silver exchanged materials were dried at room temperature and atmospheric conditions in a dark area. The resulting materials were then stored in a dark area until they were dehydrated in vacuo prior to analysis.

The $\mathrm{Li}_{x} A g_{y}$-zeolites (which may more accurately be referred to as $\mathrm{Li}_{x} \mathrm{Na}_{y} \mathrm{Ag}_{\mathrm{z}}$-zeolites, since ion exchange is rarely exhaustive and there is almost always some residual $\mathrm{Na}^{+}$ present in the starting Li-zeolite) were prepared by ion exchange of a Li-zeolite (prepared as described earlier) with a $0.05-\mathrm{M}$ solution of $\mathrm{AgNO}_{3}$. This silver solution contained a cation content that was equivalent to the targeted amount. This is possible with silver ion-exchange because the silver cation is quickly and easily exchanged (Breck, 1984). The sil- 
Table 1. Elemental Composition of the $\mathrm{Li}_{\mathrm{x}} \mathrm{Ag}_{\mathrm{y}}-\mathrm{LSX}$ Zeolite Samples

\begin{tabular}{ccccccccccccc}
\hline & \multicolumn{2}{c}{ Sample 1 } & \multicolumn{2}{c}{ Sample 2 } & \multicolumn{2}{c}{ Sample 3 } & \multicolumn{2}{c}{ Sample 4 } & \multicolumn{3}{c}{ Sample 5 } & \multicolumn{3}{c}{ Sample 6 } \\
Comp. & wt. \% & $+/-$ & wt. \% & $+/-$ & wt. \% & $+/-$ & wt. \% & $+/-$ & wt. \% & $+/-$ & wt. \% & $+/-$ \\
\hline A I & 21.38 & 0.88 & 21.19 & 0.87 & 20.80 & 0.85 & 19.45 & 0.81 & 18.37 & 0.75 & 11.91 \\
A g & 0.00 & - & 0.93 & 0.06 & 3.04 & 0.06 & 9.57 & 0.16 & 15.64 & 0.12 & 55.49 \\
Na & 0.28 & 0.02 & 0.14 & 0.01 & 0.10 & 0.01 & 0.11 & 0.01 & 0.22 & 0.01 & 0.03 & 0.01 \\
Li & 5.59 & & 5.21 & - & 4.99 & - & 4.76 & - & 3.85 & - & 0.00 & - \\
\hline
\end{tabular}

Note: Lithium was measured by inductively coupled plasma-mass spectroscopy (ICP-M S). All others were measured by neutron activation analysis (NAA).

ver ion-exchange solution was heated to a mild boil and immediately allowed to cool and settle. The resulting material was vacuum filtered and washed with copious amounts of deionized water. Complete incorporation of the targeted silver ions was verified when no precipitation was observed in the filtered water upon treatment with $\mathrm{Cl}^{-}$. These mixed-cation zeolites were then dried at room temperature and atmospheric conditions in a dark area and were stored in a dark area until they were dehydrated in vacuo prior to analysis.

The samples were compositionally characterized using neutron activation analysis (NAA) at the research nuclear reactor of the Phoenix M emorial Laboratory at the $U$ niversity of $M$ ichigan. The samples were irradiated sequentially for one minute at a core-face location with an average thermal neutron flux of $2 \times 10^{12} \mathrm{~N} / \mathrm{cm}^{2} / \mathrm{s}$. T wo separate gamma-ray spectra were collected for $500 \mathrm{~s}$ real time for each sample using a high-resolution germanium detector. A fter a 13-min decay the collection was used to determine the concentrations of aluminum and silver, while data collected after $1 \mathrm{~h}$ and $56 \mathrm{~min}$ decay were used to analyze for sodium and potassium. Four replicates of NBS-SRM-1633a (coal fly ash) and silver foil were used as standard reference materials and check standards.

The samples were also analyzed for Li content using an inductively coupled plasma mass spectrometer (ICP-MS, H ewlett-Packard HP 4500). The samples were first digested in concentrated nitric acid solution at $100^{\circ} \mathrm{C}$ for $20 \mathrm{~min}$. At the end of digestion, the samples were further diluted and filtered before the ICP-MS analyses. R esults of these analyses are given in Table 1. The unit cell compositions for those analyzed samples are given in Table 2.

From this point, all samples will be identified according to the type of zeolite and the number of charge-compensating cation(s) present in a unit cell. For example $\mathrm{Li}_{86}-\mathrm{X}$ refers to an $\mathrm{X}$-type zeolite (with $\mathrm{Si} / \mathrm{Al} \approx 1.25$ ) that has been fully exchanged to contain $86 \mathrm{Li}^{+}$cations per unit cell. The sample $\mathrm{Li}_{94.2} \mathrm{~A} \mathrm{~g}_{1.1} \mathrm{Na}_{0.7}-\mathrm{LSX}$ refers to a low-silica $X$-type zeolite (with $\mathrm{Si} / \mathrm{Al}=1.0$ ) that contains, on average, $94.2 \mathrm{Li}^{+}, 1.1 \mathrm{Ag}^{+}$

Table 2. Unit-Cell Composition for Each of the $L i_{x} A g_{y}-L S X$ Samples

\begin{tabular}{|c|c|c|c|c|c|c|}
\hline $\mathrm{atm} / \mathrm{UC}$ & $\stackrel{1}{\operatorname{tm} / \mathrm{U}}$ & ${ }_{m}^{2} \mathrm{UC}$ & $\stackrel{3}{\mathrm{tm} / \mathrm{U} C}$ & $\begin{array}{c}4 \\
\operatorname{atm} / \mathrm{U} C\end{array}$ & $\begin{array}{c}5 \\
\mathrm{~atm} / \mathrm{U} C\end{array}$ & $\begin{array}{c}6 \\
\operatorname{atm} / \mathrm{U} C\end{array}$ \\
\hline Al & 96.0 & 96.0 & 96.0 & 96.0 & 96.0 & 96.0 \\
\hline $\mathrm{Ag}$ & 0.0 & 1.1 & 3.5 & 11.5 & 21.0 & 95.7 \\
\hline $\mathrm{Na}$ & 1.5 & 0.7 & 0.5 & 0.6 & 1.2 & 0.3 \\
\hline $\mathrm{Si}$ & 96.0 & 96.0 & 96.0 & 96.0 & 96.0 & 96.0 \\
\hline $\mathrm{Li}$ & 94.5 & 94.2 & 92.0 & 83.9 & 73.8 & 0.0 \\
\hline 0 & 384.0 & 384.0 & 384.0 & 384.0 & 384.0 & 384.0 \\
\hline
\end{tabular}

(or other form of $\mathrm{Ag}$ ), and $0.7 \mathrm{Na}^{+}$per unit cell, as determined from the neutron activation (NA) and ICP-MS analyses.

\section{Structural Characterization}

A separate set of mixed Li,A g-LSX zeolites was prepared using the previously described procedure. These samples were used in the structural characterization. They were chemically characterized using neutron activation analysis (as described earlier). The unit-cell composition for each of the materials is listed in Table 3.

\section{Neutron powder diffraction}

Powder neutron diffraction data were collected for each of the samples shown in Table 3. Each of the samples was initially dehydrated under vacuum for $12 \mathrm{~h}$ at a prescribed temperature (as given in the sample name). The samples were exposed to atmospheric conditions during transport to the NIST Center for Neutron R esearch. In preparation for the diffraction experiment, approximately $10-15 \mathrm{~mL}$ of each sample was dehydrated under vacuum ( $<10^{-5}$ torr). E ach sample was heated to the temperature that was used in the prior heat treatment. Samples were heated at a rate of approximately $10^{\circ} \mathrm{C} / \mathrm{min}$, held at constant temperature for a minimum of $4 \mathrm{~h}$, then were allowed to cool to room temperature. The samples were transferred to $50-\mathrm{mm}$-long and 15.6$\mathrm{mm}$-wide vanadium cans and subsequently sealed in a helium environment with low water and oxygen levels ( $<10 \mathrm{ppm}$ ). Neutron diffraction data were collected using the 32 detector BT-1 neutron powder diffractometer at the NIST Center for Neutron R esearch NBSR reactor (G aithersburg, MD). M easurements were made using a $\mathrm{Ge}(311)$ monochromator with $\lambda=2.0783(2) \AA\left(1 \AA=10^{-10} \mathrm{~m}\right)$ at ambient temperature. Data were collected over the range of $1.3-166.3^{\circ} 2 \theta$ with a step size of $0.05^{\circ}$. The data collection time for each sample was approximately $8 \mathrm{~h}$.

Table 3. Unit-Cell Composition (in atoms/unit cell) for Each $\mathrm{Li}_{\mathrm{x}} \mathrm{Ag}_{\mathrm{y}}$ - LSX Sample Used in the Structural Determination

\begin{tabular}{cccc}
\hline Component & \multicolumn{2}{c}{$\begin{array}{c}\mathrm{Li}-\mathrm{LSX} \\
\mathrm{atm} / \mathrm{UC}\end{array}$} & $\begin{array}{c}\mathrm{Li}_{\mathrm{x}} \mathrm{Ag} \mathrm{g}_{\mathrm{y}}-\mathrm{LSX} \\
\mathrm{atm} / \mathrm{CC}\end{array}$ \\
\hline $\mathrm{Al}$ & 96 & 96 & 96 \\
$\mathrm{Ag}$ & 0 & 2.0 & 41.8 \\
$\mathrm{Na}$ & 0.2 & 0.7 & 0.2 \\
$\mathrm{Si}$ & 96 & 96 & 96 \\
$\mathrm{O}$ & 384 & 384 & 384 \\
$\mathrm{Li}$ & 95.8 & 93.3 & 54 \\
\hline
\end{tabular}


Table 4. Cell Parameters and Agreement Factors for the Four Li,Ag- LSX Samples

\begin{tabular}{|c|c|c|c|c|}
\hline Parameter & $\begin{array}{l}\text { Li }_{95.8} \mathrm{Na}_{0.2}- \\
\text { LSX }-450\end{array}$ & $\begin{array}{c}\mathrm{Li}_{54.0} \mathrm{Ag}_{41.8} \mathrm{Na}_{0.2}- \\
\text { LSX -450 }\end{array}$ & $\begin{array}{c}\mathrm{Li}_{93.3} \mathrm{Ag} \mathrm{g}_{2.0} \mathrm{Na}_{0.7^{-}} \\
\text {LSX }-350\end{array}$ & $\begin{array}{c}\mathrm{Li}_{93.3} \mathrm{Ag}_{2.0} \mathrm{Na}_{0.7}- \\
\text { LSX-450 }\end{array}$ \\
\hline Space group & $\mathrm{Fd} \overline{3}(203)$ & $\mathrm{Fd} \overline{3}(203)$ & $\mathrm{Fd} \overline{3}(203)$ & $\mathrm{Fd} \overline{3}(203)$ \\
\hline $\begin{array}{l}\mathrm{a}=\mathrm{b}=\mathrm{c}(\AA) \\
\mathrm{R}_{\text {wp }}(\mathrm{R} \text { ietveld }) \\
\mathrm{R}_{\text {Bragg }} \text { (R ietveld) } \\
\chi^{2} \text { (R ietveld) }\end{array}$ & $\begin{array}{l}24.68256(27) \\
0.0513 \\
0.0424 \\
1.352\end{array}$ & $\begin{array}{l}24.72728(33) \\
0.0579 \\
0.0456 \\
1.456\end{array}$ & $\begin{array}{l}24.68317(30) \\
0.0510 \\
0.0421 \\
1.233\end{array}$ & $\begin{array}{l}24.68379(28) \\
0.0514 \\
0.0421 \\
1.319\end{array}$ \\
\hline
\end{tabular}

Note: The agreement factors for each crystallographic model is compared to an ideal (Le Bail) fit. Standard uncertainties are given in parentheses. Definitions for $R_{w p}$ and $\chi^{2}$ can be found in $F$ reeman et al. (1991) and $R_{B r a g g}=\sum\left|F_{0}^{2}-F_{c}^{2}\right| / \sum F_{0}^{2}$.

\section{Rietudd refinement}

Neutron powder diffraction data were analyzed using the $R$ ietveld (1967) technique in conjunction with the generalized structure analysis system (GSAS) suite of Larson and Von D reele (1986). To determine the best expected fit to the data, the Le Bail intensity extraction method was used first, in effect simulating a fit with an idealized crystallographic model (Le Bail et al., 1988). Background was fit using a Chebyshev polynomial with a variable number of terms (between 8 and 12). Lattice constants and zero-point shifts were then introduced and optimized. The peak asymmetry at low angles was treated using the model of Finger et al. (1994). Scattering factors and lengths were set to standard values for neutral atoms, as supplied in the GSAS package. Initial fractional atomic coordinates for the framework constituents in space group $\mathrm{Fd} \overline{3}(203)$ were based upon the model determined by Feuerstein and Lobo (1998) for Li-LSX. In this refinement, since the material is an aluminum-saturated zeolite, T(1) is modeled as a pure Si site and T(2) is modeled as a pure AI site. The isotropic atomic displacement parameters were grouped, using one value for framework $\mathrm{T}$ atoms, a second value for framework 0 atoms, and a third for extraframework cations. Details concerning the location of extraframework cations for each material and the final stages of refinement are given in the following sections. The results of the $R$ ietveld refinement are given in Tables $4-8$. The results of the $\mathrm{R}$ ietveld refinements are summarized in Table 4 . Positional coordinates, occupancies, and atomic displacement parameters for each sample are listed in Tables 5 and 6 . Selected bond lengths ( $A$ ) and angles (degrees) are given in Tables 7 and 8 . A comparison of the cation site occupancies determined in this study is given in Table 9.

\section{$L i_{95.8} \mathrm{Na}_{0.2}-\mathbf{L S X}$ structure}

The results of the $\mathrm{R}$ ietveld refinement for this near fully $\mathrm{Li}$-exchanged zeolite are shown in Table 4. The agreement of the experimental and the refined model were quite good ( $\chi^{2}$ $=1.352$ ) and agreed very well with results reported from a previous study by Feuerstein and Lobo (1998). A Imost all of the lithium cations were located (93.5 of the 95.8 expected).

Table 5. Framework Atomic Parameters for the Li,Ag- LSX Samples from Rietveld Refinements of Neutron Powder Diffraction Data

\begin{tabular}{|c|c|c|c|c|c|c|}
\hline A tom & Site & & $\begin{array}{l}\mathrm{Li}_{95.8} \mathrm{Na}_{0.2^{-}} \\
\mathrm{LSX}-450^{-}\end{array}$ & $\begin{array}{c}\mathrm{Li}_{54.0} \mathrm{Ag}_{41.8} \mathrm{Na}_{0.2}- \\
\text { LSX }-450\end{array}$ & $\begin{array}{c}\mathrm{Li}_{93.3} \mathrm{Ag}_{2.0} \mathrm{Na}_{0.7}- \\
\text { LSX-350 }\end{array}$ & $\begin{array}{c}\mathrm{Li}_{93.3} \mathrm{Ag}_{2.0} \mathrm{Na}_{0.7}- \\
\text { LSX-450 }\end{array}$ \\
\hline \multirow[t]{2}{*}{$\mathrm{T}(1)^{*}$} & $96 \mathrm{~g}$ & $\begin{array}{l}x \\
y \\
z\end{array}$ & $\begin{array}{r}-0.0475(4) \\
0.1254(4) \\
0.0392(4)\end{array}$ & $\begin{array}{r}-0.0485(4) \\
0.1258(4) \\
0.0368(5)\end{array}$ & $\begin{array}{r}-0.0477(4) \\
0.1256(4) \\
0.0397(4)\end{array}$ & $\begin{array}{c}-0.04875(29) \\
0.1247(4) \\
0.0373(4)\end{array}$ \\
\hline & & $B\left(\AA^{2}\right)^{* *}$ & 0.011425 & 0.01514 & 0.01299 & 0.01223 \\
\hline $\mathrm{T}(2)^{*}$ & $96 \mathrm{~g}$ & $\begin{array}{l}x \\
y \\
z\end{array}$ & $\begin{array}{r}-0.0528(4) \\
0.0361(5) \\
0.1224(4)\end{array}$ & $\begin{array}{r}-0.0498(4) \\
0.0384(5) \\
0.1221(4)\end{array}$ & $\begin{array}{r}-0.0523(4) \\
0.0359(5) \\
0.1226(4)\end{array}$ & $\begin{array}{c}-0.05009(34) \\
0.0378(4) \\
0.1229(4)\end{array}$ \\
\hline \multirow[t]{2}{*}{$O(1)$} & $96 \mathrm{~g}$ & $\begin{array}{l}\mathrm{x} \\
\mathrm{y} \\
\mathrm{z}\end{array}$ & $\begin{array}{r}-0.10383(2) \\
0.00341(3) \\
0.09756(2)\end{array}$ & $\begin{array}{r}-0.1023(4) \\
0.0021(5) \\
0.0967(4)\end{array}$ & $\begin{array}{c}-0.10306(2) \\
0.00381(32) \\
0.09785(23)\end{array}$ & $\begin{array}{r}-0.10426(21) \\
0.00367(31) \\
0.09684(22)\end{array}$ \\
\hline & & $B\left(\AA^{2}\right)^{* *}$ & 0.0195 & 0.01861 & 0.02099 & 0.02023 \\
\hline$O(2)$ & $96 \mathrm{~g}$ & $\begin{array}{l}x \\
y \\
z\end{array}$ & $\begin{array}{r}0.00060(3) \\
-0.00129(3) \\
0.15314(1)\end{array}$ & $\begin{array}{r}-0.00040(33) \\
-0.00026(33) \\
0.15355(19)\end{array}$ & $\begin{array}{r}0.00052(30) \\
-0.00148(29) \\
0.15358(15)\end{array}$ & $\begin{array}{r}0.00027(26) \\
-0.00093(26) \\
0.15300(15)\end{array}$ \\
\hline $0(3)$ & $96 \mathrm{~g}$ & $\begin{array}{l}x \\
y \\
z\end{array}$ & $\begin{array}{r}-0.02202(1) \\
0.07273(3) \\
0.06963(3)\end{array}$ & $\begin{array}{r}-0.02227(19) \\
0.07392(31) \\
0.06850(35)\end{array}$ & $\begin{array}{r}-0.02261(15) \\
0.07289(29) \\
0.06875(28)\end{array}$ & $\begin{array}{r}-0.02232(15) \\
0.07333(26) \\
0.06920(27)\end{array}$ \\
\hline$O(4)$ & $96 \mathrm{~g}$ & $\begin{array}{l}x \\
y \\
z\end{array}$ & $\begin{array}{r}-0.07403(1) \\
0.08149(3) \\
0.17121(3)\end{array}$ & $\begin{array}{c}-0.07414(23) \\
0.0808(4) \\
0.1717(4)\end{array}$ & $\begin{array}{r}-0.07399(17) \\
0.08120(32) \\
0.17176(29)\end{array}$ & $\begin{array}{r}-0.07414(17) \\
0.08156(29) \\
0.17165(27)\end{array}$ \\
\hline
\end{tabular}

Note: Standard uncertainties are given in parentheses.

*The T (1) site is completely occupied by Si; the T(2) site is completely occupied by A I.

**D isplacement parameters were fixed for each refinement as follows: $T(1)=T(2), O(1)=O(2)=O(3)=O(4)$. 
Table 6. Extraframework Atomic Parameters for the Li,Ag-LSX Samples from Rietveld Refinements of Neutron Powder Diffraction Data

\begin{tabular}{|c|c|c|c|c|c|c|}
\hline A tom & Site & & $\begin{array}{l}\mathrm{Li}_{95.8} \mathrm{Na}_{0.2}- \\
\text { LSX -450 }\end{array}$ & $\begin{array}{c}\mathrm{Li}_{54.0} \mathrm{Ag}_{41.8} \mathrm{Na}_{0.2}- \\
\text { LSX-450 }\end{array}$ & $\begin{array}{c}\mathrm{Li}_{93.3} \mathrm{Ag}_{2.0} \mathrm{Na}_{0.7^{-}} \\
\text {LSX }-350\end{array}$ & $\begin{array}{l}\mathrm{Li}_{93.3} \mathrm{Ag}_{2.0} \mathrm{Na}_{0.7}- \\
\quad \text { SXX-450 }\end{array}$ \\
\hline \multirow[t]{2}{*}{$\mathrm{Li}\left(\mathrm{I}^{\prime}\right)$} & \multirow[t]{2}{*}{$32 \mathrm{e}$} & $\begin{array}{l}x=y=z \\
\text { Occup. }\end{array}$ & $\begin{array}{l}0.0455(5) \\
0.85(4)\end{array}$ & $\begin{array}{l}0.0403(7) \\
0.73(4)\end{array}$ & $\begin{array}{l}0.0438(4) \\
0.890(31)\end{array}$ & $\begin{array}{l}0.0452(4) \\
0.915(32)\end{array}$ \\
\hline & & $B\left(\AA^{2}\right)$ & 0.0415 & 0.02739 & 0.03054 & 0.03325 \\
\hline \multirow[t]{2}{*}{ Li(II) } & \multirow[t]{2}{*}{$32 \mathrm{e}$} & $\begin{array}{l}x=y=z \\
\text { Occup. }\end{array}$ & $\begin{array}{l}0.2227(4) \\
1.06(4)\end{array}$ & $\begin{array}{l}0.2228(7) \\
1.26(8)\end{array}$ & $\begin{array}{l}0.2230(4) \\
1.09(4)\end{array}$ & $\begin{array}{l}0.2237(4) \\
1.09(4)\end{array}$ \\
\hline & & $B\left(\AA^{2}\right)$ & 0.0305 & - & - & - \\
\hline \multirow[t]{2}{*}{ Li(III) } & \multirow[t]{2}{*}{$96 \mathrm{~g}$} & $\begin{array}{c}x \\
y \\
z \\
\text { Occup. }\end{array}$ & $\begin{array}{l}0.395(5) \\
0.399(5) \\
0.1264(2) \\
0.337(24)\end{array}$ & $\begin{array}{l}- \\
- \\
-\end{array}$ & $\begin{array}{l}0.3885(20) \\
0.4052(19) \\
0.1287(20) \\
0.240(16)\end{array}$ & $\begin{array}{l}0.401(4) \\
0.4038(33) \\
0.1260(16) \\
0.264(16)\end{array}$ \\
\hline & & $B\left(\AA^{2}\right)$ & 0.1201 & - & - & - \\
\hline $\mathrm{Ag}\left(\mathrm{I}^{\prime}\right)$ & $32 \mathrm{e}$ & $\begin{array}{l}x=y=z \\
\text { O ccup. }\end{array}$ & - & $\begin{array}{l}0.0818(34) \\
0.058(11)\end{array}$ & - & - \\
\hline Ag(II') & $32 \mathrm{e}$ & $\begin{array}{l}x=y=z \\
\text { O ccup. }\end{array}$ & - & - & $\begin{array}{l}0.1674(28) \\
0.053(8)\end{array}$ & $\begin{array}{l}0.170(6) \\
0.029(7)\end{array}$ \\
\hline $\mathrm{Ag}(\mathrm{II})$ & $32 \mathrm{e}$ & $\begin{array}{c}x=y=z \\
\text { O ccup. }\end{array}$ & - & $\begin{array}{l}0.203(5) \\
0.062(22)\end{array}$ & - & - \\
\hline $\mathrm{Ag}(\mathrm{II} *)$ & $32 \mathrm{e}$ & $\begin{array}{l}x=y=z \\
\text { Occup. }\end{array}$ & - & $\begin{array}{l}0.2560(34) \\
0.053(16)\end{array}$ & - & $\begin{array}{l}0.263(5) \\
0.029(7)\end{array}$ \\
\hline A g(III) & $96 \mathrm{~g}$ & $\begin{array}{c}x \\
y \\
z \\
\text { O ccup. }\end{array}$ & $\begin{array}{l}- \\
- \\
-\end{array}$ & $\begin{array}{l}0.269(5) \\
0.359(5) \\
0.123(5) \\
0.053(12)\end{array}$ & $\begin{array}{l}- \\
- \\
-\end{array}$ & $\begin{array}{l}- \\
- \\
-\end{array}$ \\
\hline Ag(III') & $96 \mathrm{~g}$ & $\begin{array}{c}x \\
y \\
z \\
\text { Occup. }\end{array}$ & $\begin{array}{l}- \\
- \\
-\end{array}$ & $\begin{array}{l}0.3924(27) \\
0.3912(28) \\
0.1451(9) \\
0.186(7)\end{array}$ & $\begin{array}{l}- \\
- \\
-\end{array}$ & $\begin{array}{l}- \\
- \\
-\end{array}$ \\
\hline Al(Alum) & $8 a$ & $\begin{array}{l}x=y=z \\
\text { O ccup. }\end{array}$ & - & $\begin{array}{l}0.125(0) \\
0.037(12)\end{array}$ & - & - \\
\hline $\mathrm{O}$ (Alum) & $32 \mathrm{e}$ & $\begin{array}{l}x=y=z \\
\text { O ccup. }\end{array}$ & - & $\begin{array}{l}0.174(6) \\
0.037(12)\end{array}$ & - & - \\
\hline
\end{tabular}

Note: Standard uncertainties are given in parentheses.

D isplacement parameters were fixed for each refinement as follows: $A g(I)=A g\left(I^{\prime}\right)=A g\left(I^{\prime \prime}\right)=A g\left(I I^{\prime}\right)=A g\left(I I^{\prime}\right)=A g(I I I)=A I(A \mid u m)=0(A \mid u m)$.

The lithium cations were located in the six-ring sites, $\mathrm{SI}^{\prime}$ and SII, and in the supercage 4-ring SIII site. A slight overpopulation was located at the SII site (33.9 cations); this was also the case with the study by Feuerstein and Lobo (1998).

Lithium cations in the SII site were at a distance of $1.97 \AA$ from the closest framework oxygen (that is, $\mathrm{Li}(\mathrm{II}) \_\mathrm{O}(2)=1.97$ A). This short distance allows the cation to sit very deep in the face of the six-ring, effectively shielding the electrostatic energy of the cation and preventing interaction with adsorbates such as nitrogen, oxygen, and argon. The sodalite cage and double six-ring (hexagonal prism) showing the sites of lithium is shown in Figure 2.

\section{$\mathrm{Li}_{54.0} \mathrm{Ag}_{41.8} \mathrm{Na}_{0.2}$ - LSX structure}

The results of the $\mathrm{R}$ ietveld refinement for the $\mathrm{Li}_{54.0} \mathrm{Ag}_{41.8} \mathrm{Na}_{0.2}-\mathrm{LSX}$ zeolite are shown in Table 4, and the agreement of the experimental and the refined model were very good ( $\left.\chi^{2}=1.456\right)$. The lithium cations of this sample were located only in the six-ring sites, $\mathrm{SI}^{\prime}$ and SII. No site SIII supercage lithium cations were located. As with the near fully Li-exchanged sample, an overpopulation of Li was located at the SII site (40.3 cations). However, if one assumes that only $32 \mathrm{Li}$ cations are located at this site, the total is very near the expected total value of lithium (55.4 of the expected 54.0). Because of this, it is likely that the GSA S suite, using $R$ ietveld refinement, consistently overestimates the population of SII lithium.

M ost of the silver was found in the SIII supercage sites (approximately $80 \%$ of the total found). This is an indication that the smaller lithium cations, when in competition with silver cations, prefer to occupy the six-ring sites. However, it may also be the result of the order of ion exchange. Since the low-silica $X$-zeolite was first ion exchanged with lithium, and then subsequently with silver, the lithium cations had the first opportunity to occupy the more energetically favorable sixring sites. If the ion exchange was done in the opposite order, silver cation may very well have retained occupancy of the six-ring sites (for silver, those would include $\mathrm{SI}, \mathrm{SI}^{\prime}, \mathrm{SII}^{\prime}, \mathrm{SII}$, and SII*; see Figure 3).

Small amounts of silver were also located in sodalite six-ring sites ( $\mathrm{SI}^{\prime}, \mathrm{SII}$, and $\left.\mathrm{SI}{ }^{*}\right)$. There was no silver associated with the single six-ring ( $\mathrm{SI}$ ) or inside the sodalite cage (SII'). The 
Table 7. Selected Interatomic Distances $\left(\AA \stackrel{\AA}{)}\right.$ ) and Bond Angles $\left(^{\circ}\right)$ Derived from Li,Ag- LSX Samples with Standard Uncertainties in Parentheses

\begin{tabular}{|c|c|c|c|c|}
\hline A toms & $\begin{array}{c}\mathrm{Li}_{95.8} \mathrm{Na}_{0.2}- \\
\text { LSX-450 }\end{array}$ & $\begin{array}{c}\mathrm{Li}_{54.0} \mathrm{Ag}_{41.8} \mathrm{Na}_{0.2}- \\
\text { LSX -450 }\end{array}$ & $\begin{array}{c}\mathrm{Li}_{93.3} \mathrm{Ag}_{2.0} \mathrm{Na}_{0.7^{-}} \\
\text {LSX-350 }\end{array}$ & $\begin{array}{c}\mathrm{Li}_{93.3} \mathrm{Ag}_{2.0} \mathrm{Na}_{0.7}- \\
\text { LSX-450 }\end{array}$ \\
\hline $\begin{array}{l}\text { Vector } \\
\text { T(1)_T(2) } \\
\text { T(1)_T(2) } \\
\text { T(1)_T( (2) } \\
\text { T(1)_O(1) } \\
\text { T(1)_O(2) } \\
\text { T(1)_O(3) } \\
\text { T(1)_O(4) }\end{array}$ & $\begin{array}{l}3.016(8) \\
3.069(8) \\
3.089(9) \\
1.708(12) \\
1.637(13) \\
1.627(13) \\
1.586(11)\end{array}$ & $\begin{array}{l}3.020(9) \\
3.034(10) \\
3.096(10) \\
1.637(9) \\
1.655(14) \\
1.637(9) \\
1.614(9)\end{array}$ & $\begin{array}{l}3.015(8) \\
3.070(8) \\
3.077(9) \\
1.731(11) \\
1.648(13) \\
1.609(13) \\
1.569(11)\end{array}$ & $\begin{array}{l}3.011(7) \\
3.036(8) \\
3.095(8) \\
1.639(8) \\
1.648(11) \\
1.630(8) \\
1.607(8)\end{array}$ \\
\hline $\begin{array}{l}\mathrm{T}(2) \_O(1) \\
\mathrm{T}(2) \_O(2) \\
\mathrm{T}(2) \_O(3) \\
\mathrm{T}(2) \_O(4)\end{array}$ & $\begin{array}{l}1.617(14) \\
1.778(13) \\
1.759(15) \\
1.727(13)\end{array}$ & $\begin{array}{l}1.700(9) \\
1.735(10) \\
1.729(9) \\
1.723(9)\end{array}$ & $\begin{array}{l}1.604(14) \\
1.771(12) \\
1.771(14) \\
1.735(12)\end{array}$ & $\begin{array}{l}1.706(8) \\
1.736(8) \\
1.730(8) \\
1.723(8)\end{array}$ \\
\hline $\begin{array}{l}\text { Angle } \\
\text { O(1)_T(1)_O(2) } \\
O(1) \_T(1) \_O(3) \\
O(1) \_T(1) \_O(4)\end{array}$ & $\begin{array}{l}106.0(5) \\
108.3(7) \\
106.8(6)\end{array}$ & $\begin{array}{l}110.2(8) \\
106.9(8) \\
108.8(7)\end{array}$ & $\begin{array}{l}105.4(5) \\
107.0(6) \\
107.4(6)\end{array}$ & $\begin{array}{l}107.9(5) \\
110.4(6) \\
108.3(6)\end{array}$ \\
\hline $\begin{array}{l}O(2) \_T(1) \_O(3) \\
O(2) \_T(1) \_O(4) \\
O(3) \_T(1) \_O(4)\end{array}$ & $\begin{array}{l}109.5(6) \\
111.4(6) \\
114.3(6)\end{array}$ & $\begin{array}{l}107.8(7) \\
111.2(6) \\
111.8(7)\end{array}$ & $\begin{array}{l}109.5(6) \\
110.9(6) \\
116.1(6)\end{array}$ & $\begin{array}{l}108.1(5) \\
110.2(5) \\
112.0(5)\end{array}$ \\
\hline $\begin{array}{l}O(1) \_T(2) \_O(2) \\
O(1) \_T(2) \_O(3) \\
O(1) \_T(2) \_O(4)\end{array}$ & $\begin{array}{l}118.7(7) \\
108.1(6) \\
110.6(7)\end{array}$ & $\begin{array}{l}114.4(9) \\
106.6(6) \\
108.5(8)\end{array}$ & $\begin{array}{l}118.8(7) \\
107.0(6) \\
110.1(7)\end{array}$ & $\begin{array}{l}116.8(6) \\
105.8(5) \\
107.6(6)\end{array}$ \\
\hline $\begin{array}{l}O(2)-T(2) \_O(3) \\
O(2) \_T(2) \_O(4) \\
O(3) \_T(2) \_O(4)\end{array}$ & $\begin{array}{l}105.2(6) \\
105.4(6) \\
108.3(7)\end{array}$ & $\begin{array}{l}110.3(7) \\
105.2(7) \\
111.9(7)\end{array}$ & $\begin{array}{l}106.8(6) \\
105.1(6) \\
108.7(7)\end{array}$ & $\begin{array}{l}108.9(6) \\
107.0(5) \\
110.7(5)\end{array}$ \\
\hline $\begin{array}{l}\mathrm{T}(1) \_0(1) \_\mathrm{T}(2) \\
\mathrm{T}(1) \_0(2)-\mathrm{T}(2) \\
\mathrm{T}(1) \_0(3) \_\mathrm{T}(2) \\
\mathrm{T}(1) \_0(4) \_\mathrm{T}(2)\end{array}$ & $\begin{array}{l}145.5(4) \\
127.95(33) \\
125.86(31) \\
137.7(4)\end{array}$ & $\begin{array}{l}148.2(6) \\
127.0(4) \\
127.5(4) \\
136.1(5)\end{array}$ & $\begin{array}{l}146.1(4) \\
127.73(34) \\
126.26(33) \\
137.2(4)\end{array}$ & $\begin{array}{l}144.98(34) \\
127.61(33) \\
127.31(33) \\
136.6(4)\end{array}$ \\
\hline
\end{tabular}

silver site II is approximately in the plane of the six-ring. A new site, which is labeled SII* to distinguish it from the conventional SII (see Figure 3), was found in this sample. Site II* is still observed on the supercage side of the six-ring, but is shifted further away from the plane of the six-ring. Only about $70 \%$ of the expected silver was located using R ietveld refinement. One explanation for this result is that there may be reduced silver crystallites on the exterior of the zeolite. This was discussed in a previous work for near fully Ag-exchange faujasites (H utson et al., 2000). This explanation also helps to explain the higher than expected lithium. The sodalite cage and double six-ring (hexagonal prism) showing the sites for lithium and silver occupancy is shown in Figure 3.

Fourier difference analysis indicated the presence of scattering density at the center of the sodalite cage and approximately $1.7 \mathrm{~A}$ away from this site. O ne likely explanation for this extra scattering density is the presence of extraframework alumina in the center of the sodalite cage. This was also noted in a neutron diffraction structural analysis of near fully exchanged $A g-X$ and $A g-L S X$ zeolites. E ven when carefully dehydrated, $X$ and LSX tend to lose framework alumina through self-steaming to void spaces in the zeolite (the sodalite cage and supercage). A n extraframework tetrahedral $\left[\mathrm{AlO}_{2}\right]^{-}$unit was added to the model with the $\mathrm{Al}^{3+}$ located at the center of the sodalite cage and oxygen atoms along the (111) axis. The fractional occupancies for these two atoms were constrained to be the same. I sotropic atomic displace- ment parameters were constrained to be the same as that of the extraframework silver.

\section{$L i_{93.3}{A g_{2.0}} \mathrm{Na}_{0.7}-\mathbf{L S X}$ structure}

These samples contained only a small amount of silver and, as a result, there was only a slight difference in the diffraction pattern as compared to that of fully Li-exchanged LSX. This makes the $R$ ietveld refinement very difficult ( $R$ eisner, personal communication, 2000). In approaching this refinement, it was necessary to use information of the behavior of lithium and silver from the previous samples. It was also necessary to use what was already known of the behavior of silver in near fully exchanged LSX-zeolite (H utson et al., 2000).

The results of the $\mathrm{R}$ ietveld refinement for the $\mathrm{Li}_{93.3}$ $\mathrm{Ag}_{2.0} \mathrm{Na}_{0.7}-\mathrm{LSX}$ zeolite (after vacuum dehydration at $350^{\circ} \mathrm{C}$ and at $450^{\circ} \mathrm{C}$ ) are shown in Table 4; and the agreement of the experimental and the refined model were very good ( $\chi^{2}$ $=1.233$ for the sample heated to $350^{\circ} \mathrm{C}$, and $\chi^{2}=1.319$ for the sample heated to $450^{\circ} \mathrm{C}$ ). The overall structures of these samples are very similar to that described earlier for the $\mathrm{Li}_{95.8} \mathrm{Na}_{0.2}-\mathrm{LSX}$ sample. A Imost all of the lithium cations were located ( 86.4 and 89.5 of the 93.3 expected). As with the $\mathrm{Li}_{95.8} \mathrm{Na}_{0.2}-\mathrm{LSX}$ sample, the lithium cations were located in the six-ring sites, $\mathrm{SI}^{\prime}$ and SII, and the supercage 4-ring SIII site, and a slight overpopulation was located at the SII site (34.9 cations at SII for both samples). 
Table 8. Selected Interatomic Distances ( $\left(\AA^{\prime}\right)$ Derived from Li,Ag- LSX, With Standard Uncertainties in Parentheses

\begin{tabular}{|c|c|c|c|c|}
\hline A toms & $\begin{array}{c}\mathrm{Li}_{95.8} \mathrm{Na}_{0.2}- \\
\text { LSX-450 }\end{array}$ & $\begin{array}{c}\mathrm{Li}_{54.0} \mathrm{Ag}_{41.8} \mathrm{Na}_{0.2}- \\
\text { LSX -450 }\end{array}$ & $\begin{array}{c}\mathrm{Li}_{93.3} \mathrm{Ag}_{2.0} \mathrm{Na}_{0.7}- \\
\text { LSX - } 350\end{array}$ & $\begin{array}{c}\mathrm{Li}_{93.3} \mathrm{Ag}_{2.0} \mathrm{Na}_{0.7}- \\
\text { LSX-450 }\end{array}$ \\
\hline $\mathrm{Li}\left(\mathrm{I}^{\prime}\right) \_\mathrm{SI}$ & $3.030(9)$ & $3.049(10)$ & $3.031(9)$ & $3.044(8)$ \\
\hline$L i\left(I^{\prime}\right) \_A I$ & $3.090(12)$ & $3.009(12)$ & $3.073(12)$ & $3.040(10)$ \\
\hline $\mathrm{Li}\left(\mathrm{I}^{\prime}\right) \_\mathrm{O}(3)$ & $1.893(4)$ & $1.890(5)$ & $1.893(4)$ & $1.900(4)$ \\
\hline $\mathrm{Li}\left(\mathrm{I}^{\prime}\right) \_\mathrm{A} g\left(\mathrm{I}^{\prime}\right)$ & - & $1.78(14)$ & $3.337(28)$ & $3.32(6)$ \\
\hline $\mathrm{Li}(\mathrm{II}) \_\mathrm{SI}$ & $3.044(10)$ & $3.052(10)$ & $3.046(10)$ & $3.078(8)$ \\
\hline Li(II)_AI & $3.174(11)$ & $3.148(12)$ & $3.166(11)$ & $3.136(9)$ \\
\hline Li(II)_O(2) & $1.970(4)$ & $1.965(6)$ & $1.964(4)$ & $1.978(5)$ \\
\hline $\mathrm{Li}(\mathrm{II}) \_\mathrm{Ag}\left(\mathrm{II}^{\prime}\right)$ & - & - & $2.38(12)$ & $2.28(24)$ \\
\hline $\mathrm{Li}(\mathrm{II}) \_\mathrm{Ag}(\mathrm{II})$ & - & $0.87(25)$ & - & - \\
\hline Li(II)_Ag(II*) & - & $1.42(15)$ & - & $1.67(20)$ \\
\hline Li(II)_O(A lum) & - & $2.11(28)$ & - & - \\
\hline Li(III)_SI & $2.53(10)$ & - & $2.44(5)$ & $2.48(7)$ \\
\hline Li(III)_AI & $3.31(8)$ & - & $3.26(5)$ & 2.49(7) \\
\hline Li(III)_AI & $2.54(10)$ & - & $2.74(4)$ & - \\
\hline Li(III)_O(1) & $2.68(12)$ & - & $2.56(5)$ & $2.57(8)$ \\
\hline $\mathrm{Li}(\mathrm{III}) \_(1)$ & $2.57(11)$ & - & $2.73(5)$ & $2.41(9)$ \\
\hline Li(III)_O(3) & $2.81(5)$ & - & - & $2.72(4)$ \\
\hline Li(III)_O(4) & $2.11(12)$ & - & $2.00(5)$ & $2.19(9)$ \\
\hline Li(III)_O(4) & $2.23(12)$ & - & $2.45(5)$ & $2.30(8)$ \\
\hline Li(III)_Li(III) & $1.53(11)$ & - & $1.63(9)$ & $1.92(8)$ \\
\hline $\mathrm{Ag}\left(\mathrm{I}^{\prime}\right) \_\mathrm{O}(3)$ & - & $2.60(10)$ & - & - \\
\hline$A g\left(I^{\prime}\right) \_A g(I I)$ & - & $3.22(20)$ & - & - \\
\hline$A g\left(I^{\prime}\right) \_A g\left(I^{\prime}\right)$ & - & $3.02(24)$ & - & - \\
\hline A $g\left(I^{\prime}\right) \_A l(A L U M)$ & - & $1.85(14)$ & - & - \\
\hline A g(I')_O(ALU M ) & - & $2.28(19)$ & - & - \\
\hline$A g\left(\mid I^{\prime}\right) \_A g\left(I I^{\prime}\right)$ & - & - & $2.96(20)$ & $3.2(4)$ \\
\hline $\mathrm{Ag}(\mathrm{II}) \_\mathrm{Si}$ & - & $3.049(31)$ & - & - \\
\hline$A g(\mid I) \_A \mid$ & - & $3.129(32)$ & - & - \\
\hline A $g(I I) \_O(2)$ & - & $2.06(7)$ & - & - \\
\hline A $g(I I) \_O(A L U M)$ & - & $1.24(30)$ & - & - \\
\hline $\mathrm{Ag}(\mathrm{II} *) \_O(2)$ & - & $2.54(9)$ & - & - \\
\hline A $g(I I *) \_A g(I I)$ & - & $2.28(27)$ & - & - \\
\hline $\mathrm{Ag}\left(\mathrm{III} \mathrm{I}^{\prime}\right) \_\mathrm{Si}$ & - & $3.01(5)$ & - & - \\
\hline A g(III')_AI & - & $2.93(5)$ & - & - \\
\hline $\mathrm{Ag}\left(\mathrm{III} \mathrm{I}^{\prime}\right) \_O(4)$ & - & $2.44(6)$ & - & - \\
\hline$A g\left(I I I^{\prime}\right) \_A g\left(I I I^{\prime}\right)$ & - & $1.18(5)$ & - & - \\
\hline$A g(I I I \prime) \_A g(I I I)$ & - & $3.20(16)$ & - & - \\
\hline A $g\left(I I I^{\prime}\right) \_A g(I I I)$ & - & $2.26(14)$ & - & - \\
\hline A g(III)_Si & - & $2.05(13)$ & - & - \\
\hline A g(III)_AI & - & $1.89(13)$ & - & - \\
\hline A g(III)_O(1) & - & $0.73(15)$ & - & - \\
\hline A $(I I I) \_0(4)$ & - & $2.48(12)$ & - & - \\
\hline A I (A LU M )_O(A LU M ) & - & $2.08(27)$ & - & - \\
\hline
\end{tabular}

The mixed Li,A g-LSX sample that had been heated to $350^{\circ} \mathrm{C}$ only had silver located in the $\mathrm{SII}^{\prime}$ location. A Imost all of the silver was located (1.7 of the expected 2.0 per unit cell). The sample that had been heated to $450^{\circ} \mathrm{C}$, however, had a population of 0.9 silver in both SII and SII' (which provided the location of 1.8 of the $2.0 \mathrm{Ag}$ expected). The

Table 9. Selected Interatomic B ond Angles (Degrees) Derived from Li,Ag- LSX, With Standard Uncertainties in Parentheses

\begin{tabular}{|c|c|c|c|c|}
\hline A toms & $\begin{array}{l}\mathrm{Li}_{95.8} \mathrm{Na}_{0.2}- \\
\mathrm{LSX}-450\end{array}$ & $\begin{array}{c}\mathrm{Li}_{54.0} \mathrm{Ag}_{41.8} \mathrm{Na}_{0.2}- \\
\text { LSX-450 }\end{array}$ & $\begin{array}{c}\mathrm{Li}_{93.3} \mathrm{Ag}_{2.0} \mathrm{Na}_{0.7}- \\
\text { LSX-350 }\end{array}$ & $\begin{array}{c}\mathrm{Li}_{93.3} \mathrm{Ag}_{2.0} \mathrm{Na}_{0.7}- \\
\text { LSX-450 }\end{array}$ \\
\hline $\begin{array}{l}O(3) \_L i\left(I^{\prime}\right) \_O(3) \\
O(3) \_L i\left(I^{\prime}\right) \_A g\left(I^{\prime}\right)\end{array}$ & $\begin{array}{c}118.52(25) \\
-\end{array}$ & $\begin{array}{l}119.998(14) \\
90.3(9)\end{array}$ & $\begin{array}{c}119.14(17) \\
-\end{array}$ & $\begin{array}{l}118.70(22) \\
-\end{array}$ \\
\hline $\begin{array}{l}O(2) \_L i(I I) \_O(2) \\
O(2) \_L i(I I) \_A g\left(I I^{\prime}\right) \\
O(2) \_L i(I I) \_A g(I I) \\
O(2) \_L i(I I) \_A g\left(I I^{*}\right)\end{array}$ & $\begin{array}{c}118.95(17) \\
- \\
-\end{array}$ & $\begin{array}{l}118.94(31) \\
- \\
84.0(9) \\
96.0(9)\end{array}$ & $\begin{array}{c}118.90(17) \\
83.9(5) \\
- \\
-\end{array}$ & $\begin{array}{c}118.42(22) \\
82.7(5) \\
- \\
97.3(5)\end{array}$ \\
\hline SI_Li(III)_AI & 73.0(13) & - & $70.9(12)$ & $74.5(11)$ \\
\hline $\begin{array}{l}O(2) \_A g(I I) \_O(2) \\
O(2) \_A g(I I) \_A g\left(I I^{*}\right)\end{array}$ & - & $\begin{array}{r}110 .(6) \\
71 .(6)\end{array}$ & - & - \\
\hline
\end{tabular}


Table 10. Reported Site Occupancies for Extraframework Species in Li,Ag- LSX in Units of Silver/Unit Cell

\begin{tabular}{|c|c|c|c|c|}
\hline Cation & $\begin{array}{c}\mathrm{Li}_{95.8} \mathrm{Na}_{0.2^{-}} \\
\text {LSX -450 }\end{array}$ & $\begin{array}{c}\mathrm{Li}_{54.0} \mathrm{Ag}_{41.8} \mathrm{Na}_{0.2}- \\
\text { LSX -450 }\end{array}$ & $\begin{array}{c}\mathrm{Li}_{93.3} \mathrm{Ag}_{2.0} \mathrm{Na}_{0.7}- \\
\text { LSX-350 }\end{array}$ & $\begin{array}{c}\mathrm{Li}_{93.3} \mathrm{Ag}_{2.0} \mathrm{Na}_{0.7}- \\
\quad \mathrm{LSX}-450\end{array}$ \\
\hline $\begin{array}{l}\mathrm{Li}\left(\mathrm{II}^{\prime}\right) \\
\mathrm{Li}(\mathrm{II}) \\
\mathrm{Li}(\mathrm{III}) \\
\mathrm{Li} \text { found } \\
\text { Li predicted }\end{array}$ & $\begin{array}{l}27.2 \\
33.9 \\
32.4 \\
93.5 \\
95.8\end{array}$ & $\begin{array}{l}23.4 \\
40.3 \\
- \\
63.7 \\
54.0\end{array}$ & $\begin{array}{l}28.5 \\
34.9 \\
23.0 \\
86.4 \\
93.3\end{array}$ & $\begin{array}{l}29.3 \\
34.9 \\
25.3 \\
89.5 \\
93.3\end{array}$ \\
\hline $\begin{array}{l}\text { Ag( }\left(I^{\prime}\right) \\
\text { Ag(II') } \\
\text { Ag(II) } \\
\text { Ag(II*) } \\
\text { Ag(III) } \\
\text { Ag(III') } \\
\text { Ag Found } \\
\text { Ag Predicted }\end{array}$ & $\begin{array}{l}- \\
- \\
- \\
- \\
-\end{array}$ & $\begin{array}{c}1.9 \\
2.0 \\
1.7 \\
5.1 \\
17.9 \\
28.6 \\
41.8\end{array}$ & $\begin{array}{l}\overline{1.7} \\
- \\
- \\
- \\
- \\
1.7 \\
2.0\end{array}$ & $\begin{array}{l}\overline{0} \\
\overline{0} \\
0.9 \\
\overline{-} \\
\overline{1.8} \\
2.0\end{array}$ \\
\hline
\end{tabular}

sodalite cage and double six-ring (hexagonal prism) showing the sites for lithium and silver occupancy is shown in Figure 3.

\section{Adsorption \\ Adsorption isotherms}

The adsorption isotherms were measured using a static volumetric system (M icromeritics A SA P-2010). A dditions of the analysis gas were made at volumes required to achieve a targeted set of pressures. A minimum equilibrium interval of $9 \mathrm{~s}$

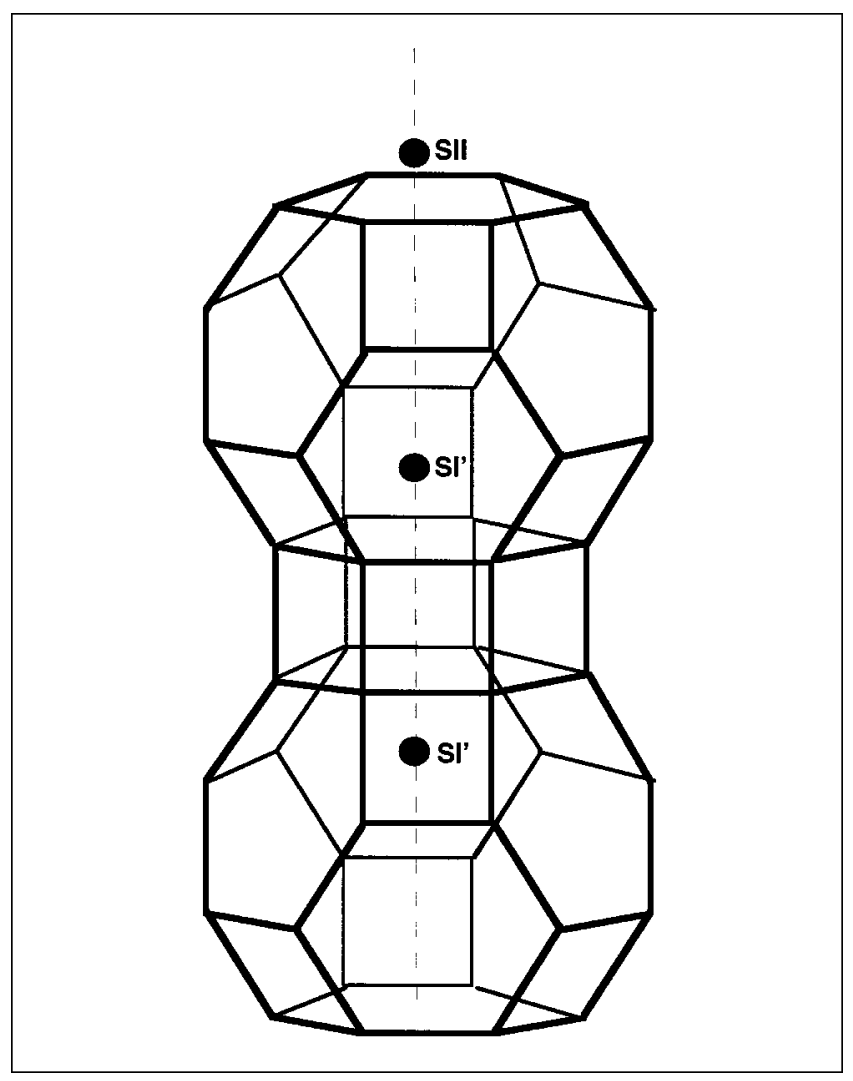

Figure 2. Position of extraframework sites in relationship to the sodalite cage in Li-LSX zeolite. with a tolerance of $5 \%$ of the target pressure (or 0.007 atm, whichever is smaller) was used to determine equilibrium for each measurement point. The pressure transducers in the A SA P-2010 are accurate to $<0.2 \%$ for the pressure range of 0-1 atm. The sample weights were obtained using a digital

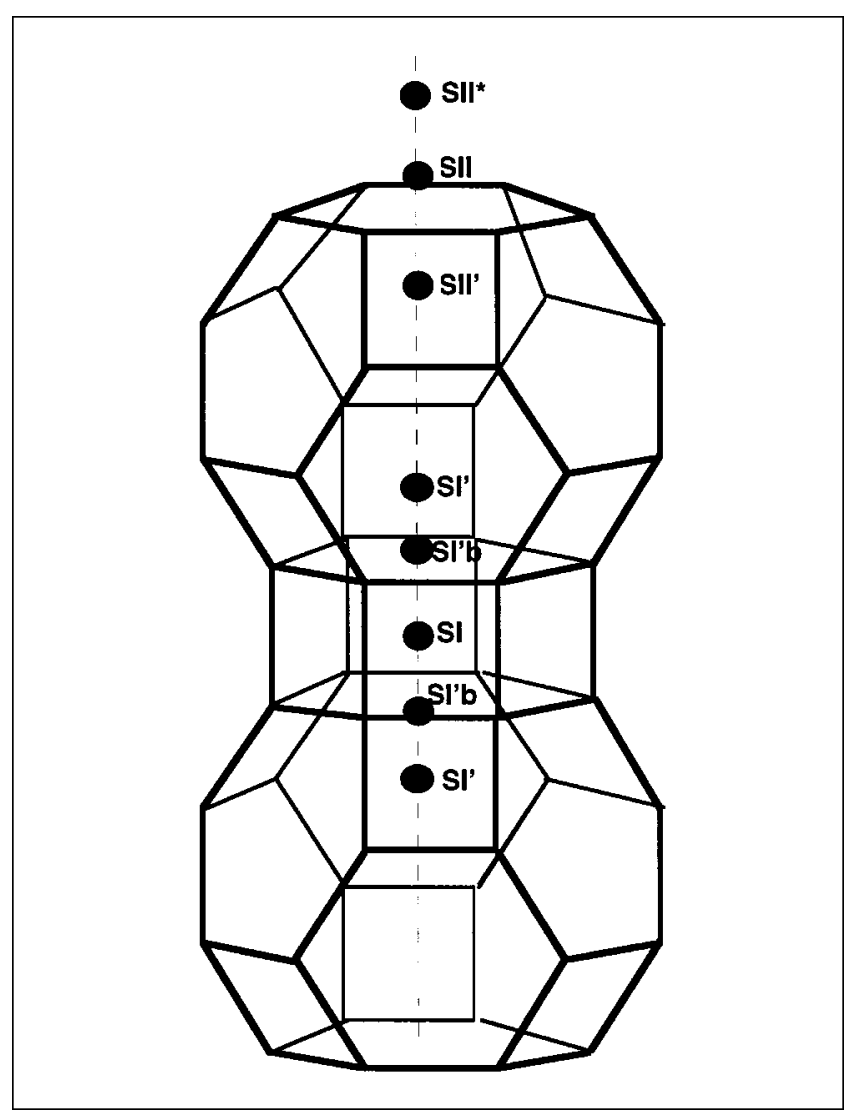

Figure 3. Position of extraframework sites in relationship to the sodalite cage in Li,Ag- LSX zeolite. Silver was found in all sites (except $S I^{\prime}$ ) for the $\mathrm{Li}_{54.0} \mathrm{~A} \mathrm{~g}_{41.8} \mathrm{Na}_{0.2}-\mathrm{LSX}-450$ (that is, dehydrated at $450^{\circ} \mathrm{C}$ ) sample. Silver was found in the SII' site only for the $\mathrm{Li}_{93.3} \mathrm{Ag}_{2.0} \mathrm{Na}_{0.7}-\mathrm{LSX}-350$ (dehydrated at $350^{\circ} \mathrm{C}$ ) sample, and in the SII' and $\mathrm{SII}^{*}$ sites for $\mathrm{Li}_{93.3} \mathrm{~A}_{2.0} \mathrm{Na}_{0.7}-\mathrm{LSX}-450$ sample. 
Table 11. Conversion Factor and Cell Density for the Mixed $\mathbf{L i}_{\mathrm{x}} \mathrm{Ag}_{\mathrm{y}}$ - Z eolites

\begin{tabular}{ccc}
\hline Sorbent & $\begin{array}{c}\text { Conv. Factor } \\
(\text { molec./mmol·UC) }\end{array}$ & $\begin{array}{c}\text { Cell Density } \\
(\mathrm{g} / \mathrm{UC}) \times 10^{20}\end{array}$ \\
\hline $\mathrm{Li}_{94.5} \mathrm{Na}_{1.5}-\mathrm{LSX}$ & 12.12047 & 2.012 \\
$\mathrm{Li}_{9.2} \mathrm{~A} \mathrm{~g}_{1.1} \mathrm{Na}_{0.7}-\mathrm{LSX}$ & 12.21865 & 2.029 \\
$\mathrm{Li}_{92.0} \mathrm{~A} \mathrm{~g}_{3.5} \mathrm{Na}_{0.5}-\mathrm{LSX}$ & 12.45768 & 2.068 \\
$\mathrm{Li}_{83.9} \mathrm{~A} \mathrm{~g}_{11.5} \mathrm{Na}_{0.6}-\mathrm{LSX}$ & 13.26673 & 2.203 \\
$\mathrm{Li}_{7.38} \mathrm{~A} \mathrm{~g}_{21.0} \mathrm{Na}_{1.2}-\mathrm{LSX}$ & 14.23573 & 2.363 \\
$\mathrm{Ag}_{9.7} \mathrm{Na}_{0.3}-\mathrm{LSX}$ & 21.76031 & 3.613 \\
$\mathrm{Ag} \mathrm{g}_{85.7} \mathrm{Na}_{0.3}-\mathrm{X}$ & 20.69265 & 3.436 \\
\hline
\end{tabular}

laboratory balance that is accurate to $\pm 0.01 \mathrm{~g}$. The isotherm measurements and the samples themselves were found to be highly reproducible. Helium (99.995\%, prepurified), oxygen (99.6\%, extra dry), nitrogen (99.998\%, prepurified), and argon $(99.998 \%$ prepurified) were obtained from Cryogenic Gases.

A dsorption isotherms are often reported as the amount (in mmol or vol-stp) of gas adsorbed per mass (in grams) of dehydrated sorbent. However, since there is a considerable change in the density of the resultant zeolite with the ion exchange of low-mass lithium cations for the much heavier silver cations, it is more meaningful to present adsorption data as the molecules of adsorbate in each unit cell of the sorbent, $\mathrm{Li}, \mathrm{Ag}$-zeolite. Conversion factors for this conversion are given for each of the samples in Table 11.

Figure 4 shows the $\mathrm{N}_{2}, \mathrm{O}_{2}$, and Ar adsorption isotherms, measured at $25^{\circ} \mathrm{C}$, for $\mathrm{Li}_{94.5} \mathrm{Na}_{1.5}-\mathrm{LSX}$ after vacuum dehydration at $350^{\circ} \mathrm{C}$. This zeolite is used in adsorptive air separation because of its very high $\mathrm{N}_{2}$ capacity and very favorable $\mathrm{N}_{2}: \mathrm{O}_{2}$ selectivity (approximately $6: 1$ at $1 \mathrm{~atm}$ ) as well as its $\mathrm{N}_{2}$ isotherm linearity. Figure 5 shows the enhancement in the $\mathrm{N}_{2}$ adsorption capacity for $\mathrm{Li}_{94.5} \mathrm{Na}_{1.5}-\mathrm{LSX}$ over that of $\mathrm{Li}_{77.0} \mathrm{Na}_{9.0}-\mathrm{X}$. The data are shown in both mmol of adsorbate per gram of sorbent (top) and molecule of adsorbate per unit cell of sorbent (bottom).

Figure 6 shows $\mathrm{N}_{2}, \mathrm{O}_{2}$, and $\mathrm{Ar}$ adsorption isotherms for $\mathrm{Ag}_{95.7} \mathrm{Na}_{0.3}-\mathrm{LSX}$, all measured at $25^{\circ} \mathrm{C}$, after vacuum dehy-

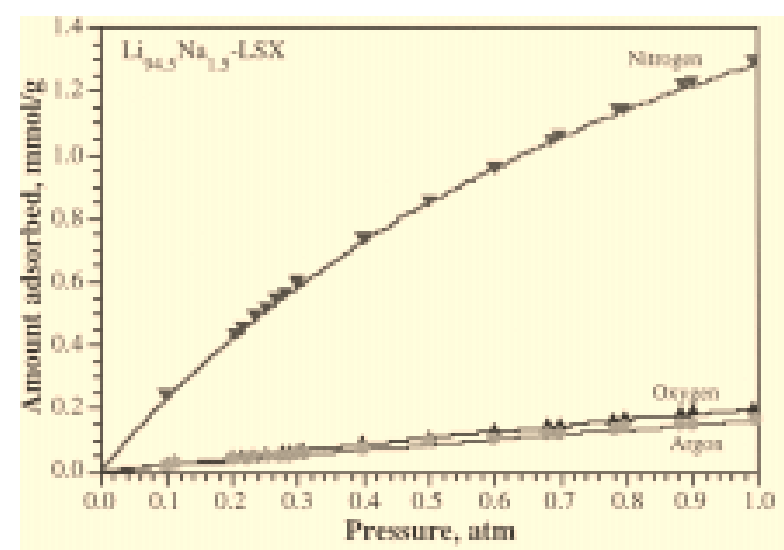

Figure 4. Single-component adsorption isotherms, measured at $25^{\circ} \mathrm{C}$, for $\mathrm{N}_{2}, \mathrm{O}_{2}$ and $\mathrm{Ar}$ on $\mathrm{Li}_{94.5} \mathrm{Na}_{1.5}$ - LSX after vacuum dehydration at $350^{\circ} \mathrm{C}$ for $4 \mathrm{~h}$.
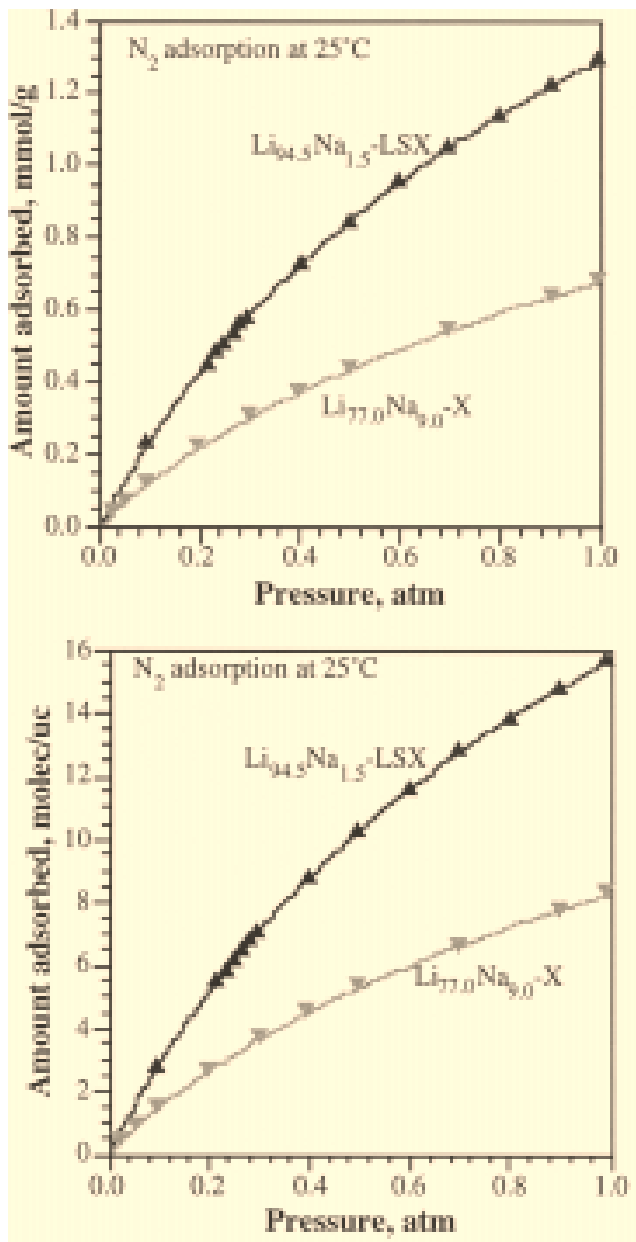

Figure 5. $\mathrm{N}_{2}$ equilibrium isotherms measured at $25^{\circ} \mathrm{C}$.

This figure shows the enhancement in the $\mathrm{N}_{2}$ adsorption capacity for $\mathrm{Li}{ }_{94.5} \mathrm{Na}_{1.5}-\mathrm{LSX}$ zeolite over that of $\mathrm{Li}{ }_{77.0} \mathrm{~N} \mathrm{a}_{9.0}-\mathrm{X}$ zeolite. Both isotherms were measured after vacuum dehydration at $350^{\circ} \mathrm{C}$ for $4 \mathrm{~h}$.

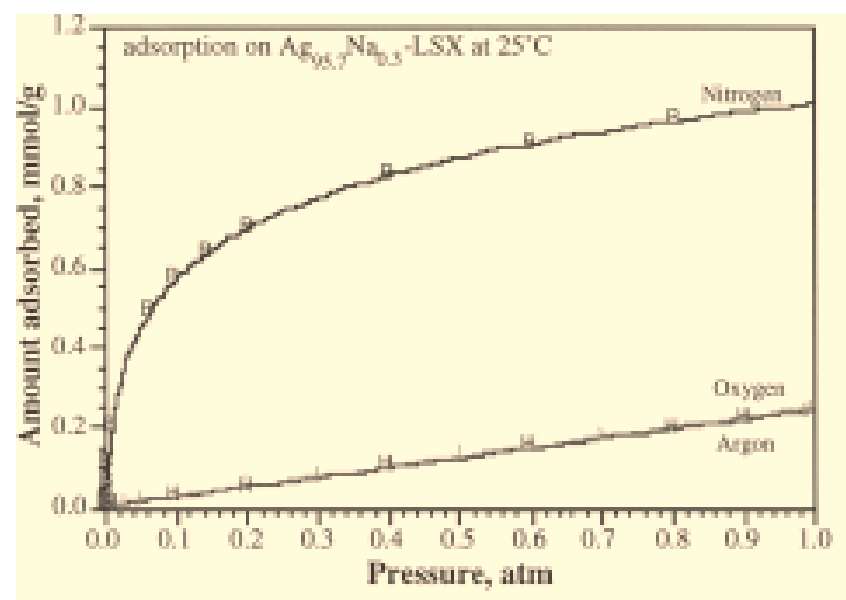

Figure 6. Single-component adsorption isotherms, measured at $25^{\circ} \mathrm{C}$, for $\mathrm{N}_{2}, \mathrm{O}_{2}$, and $\mathrm{Ar}$ on $\mathrm{Ag}_{95.7} \mathrm{Na}_{0.3}$ - LSX after vacuum dehydration at $450^{\circ} \mathrm{C}$ for $4 \mathrm{~h}$. 

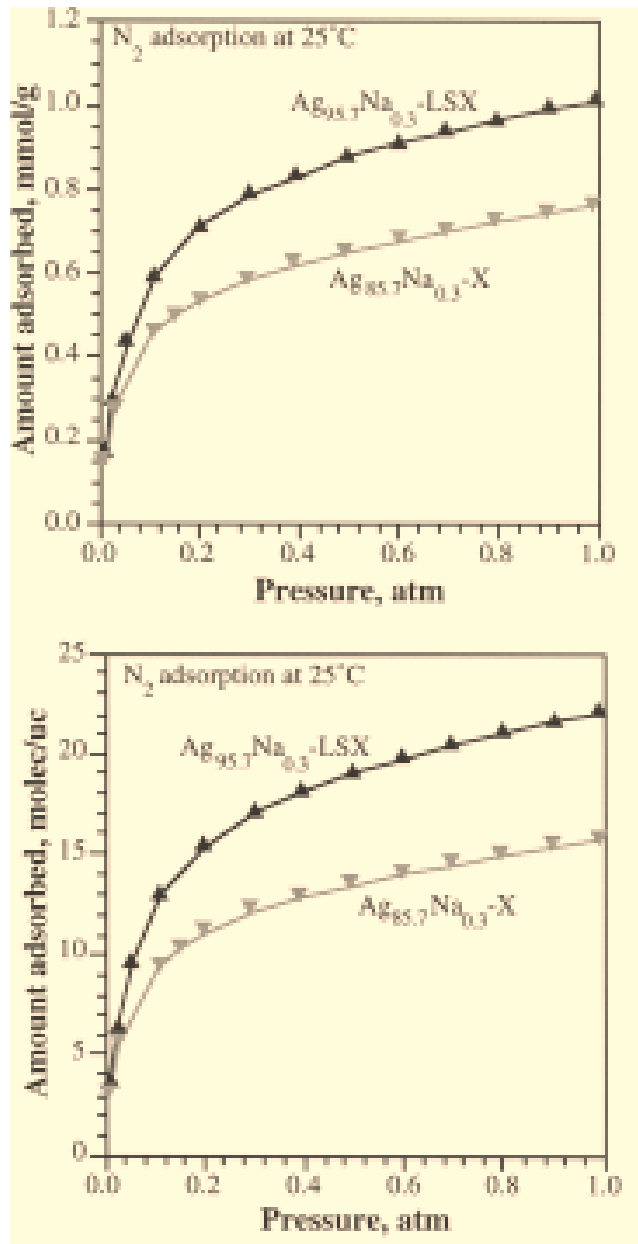

Figure 7. $\mathrm{N}_{2}$ equilibrium isotherms measured at $25^{\circ} \mathrm{C}$. This figure shows the enhancement in the $\mathrm{N}_{2}$ adsorption capacity for $\mathrm{Ag}_{95.7} \mathrm{Na}_{0.3}-\mathrm{LSX}$ over that of $\mathrm{Ag}_{85.7} \mathrm{Na}_{0.3}-\mathrm{X}$. $B$ oth isotherms were measured after vacuum dehydration at $350^{\circ} \mathrm{C}$ for $4 \mathrm{~h}$

dration at $450^{\circ} \mathrm{C}$ for a minimum of $4 \mathrm{~h}$. These samples were all initially gray in color, but after vacuum dehydration, turned to a deep golden yellow, indicating the formation of silver clusters (Sun and Seff, 1994). Figure 7 shows the enhancement in the $\mathrm{N}_{2}$ adsorption capacity for $\mathrm{Ag}_{95.7} \mathrm{Na}_{0.3}-\mathrm{LSX}$ over that of the $\mathrm{Ag}_{85.7} \mathrm{Na}_{0.3}-\mathrm{X}$. As before, the data are shown in both $\mathrm{mmol}$ of adsorbate per gram of sorbent (top) and molecule of adsorbate per unit cell of sorbent (bottom).

While the near fully exchanged A g-zeolites, like their Lizeolite analogs, have very high $\mathrm{N}_{2}$ capacity and favorable $\mathrm{N}_{2}: \mathrm{O}_{2}$ selectivity, they are not favorable for use in adsorption-based separation. Because of the strong adsorption of $\mathrm{N}_{2}$ at low pressure, creating a low-pressure "knee" in the adsorption isotherm shown in Figure 6, the working capacity (that is, the $\Delta \mathrm{Q}$, the change in the adsorptive capacity from the typically used adsorption pressure of 1.0 to a desorptive pressure of $0.33 \mathrm{~atm}$ ) is very small, and the material must be exposed to very low-pressure conditions in order to increase that working capacity.

Some A g-zeolites have been shown to have a selectivity for A r over $\mathrm{O}_{2}$ (K naebel and $\mathrm{K}$ andybin, 1993), and, in this work, the $\mathrm{Ag}$-zeolites that had been vacuum dehydrated at $350^{\circ} \mathrm{C}$ also showed a selectivity for $\mathrm{Ar}$ over $\mathrm{O}_{2}$. $\mathrm{H}$ owever, the $\mathrm{Ag}$ zeolites that had been vacuum dehydrated at $450^{\circ} \mathrm{C}$ had approximately the same adsorption capacity for $\mathrm{Ar}$ and $\mathrm{O}_{2}$ (as shown in Figures 4 and 6). This is likely due to increased interaction between the charged $\mathrm{A}$ g-clusters $\left(\mathrm{A} \mathrm{g}^{+}\right.$at $\left.\mathrm{SII}\right)$ and the quadrupole moment of the $\mathrm{O}_{2}$ molecule (whereas, the $\mathrm{Ar}$ has no quadrupole moment).

The $\mathrm{N}_{2}$ adsorption isotherms, measured at $25^{\circ} \mathrm{C}$, for $\mathrm{Li}_{x} \mathrm{~A} \mathrm{~g}_{\mathrm{y}}-\mathrm{LSX}$ zeolites after vacuum dehydration at $450^{\circ} \mathrm{C}$ for a minimum of $4 \mathrm{~h}$ are shown in Figure 8 , where the amount adsorbed is given in both $\mathrm{mmol} / \mathrm{g}$ (top) and molec/UC (bottom). These zeolites contained varying amounts of $\mathrm{Ag}$ per unit cell, ranging from zero (that is, the near fully exchanged $\mathrm{Li}_{94.5}-\mathrm{Na}_{1.5}-\mathrm{LSX}$ sample) to 21 (the $\mathrm{Li}_{73.8} \mathrm{Ag}_{21} \mathrm{Na}_{1.2}-\mathrm{LSX}$ sample). This plot reveals that the incorporation of only a small amount of silver changes the adsorptive properties of the near fully exchanged $\mathrm{Li}_{94.5} \mathrm{Na}_{1.5}-\mathrm{LSX}$ zeolite. With increasing additions of $\mathrm{Ag}^{+}$ (and corresponding removal of $\mathrm{Li}^{+}$and $\mathrm{Na}^{+}$), the adsorption isotherms begin to take on more of the characteristics of the near fully exchanged $\mathrm{Ag}_{95.3} \mathrm{Na}_{0.3}-\mathrm{LSX}$ material (that is, the high "knee" at low pressures).

\section{Heats of adsorption}

$\mathrm{H}$ eterogeneity in zeolites may result from a number of causes, including a mixed population of charge-compensating cations. If the intracrystalline cation composition is mixed, sites in the vicinity of a cation will differ for each cation whether or not they occupy equivalent crystallographic positions. Further, in a mixed cation population the proportion of one cation to another can vary from one cavity to another, so that the behavior of the cavities as multiple sorption sites may vary throughout the crystal (Barrer, 1978).

The presence of energetic heterogeneity of a system can be determined by plotting the isosteric heat of adsorption vs. the amount adsorbed. Energetic heterogeneity of the system will result in a decrease in the isosteric heat of adsorption as the amount sorbed increases. For small uptakes, the isosteric heat may decrease rather strongly with the amount adsorbed. This would be an indication that there are some local intracrystalline positions where the guest molecules are preferentially sorbed more exothermally than in the rest of the intracrystalline volume.

The measurement of adsorption isotherms at different temperatures permits the calculation of the heat of adsorption as a function of surface coverage. When experimental data are reported as a set of adsorption isotherms for a particular gas-adsorbent system, the isosteric heat of adsorption is usually calculated (Bajusz and Goodwin, 1997). The isosteric heat of adsorption can be calculated from a series of isotherms by application of the Clausius-Claperyrong equation as follows:

$$
\Delta H_{\text {ads }}=R\left(\frac{d \ln P}{d(1 / T)}\right) .
$$

$U$ sing the data from nitrogen adsorption isotherms measured at $50^{\circ} \mathrm{C}, 25^{\circ} \mathrm{C}$ and $0^{\circ} \mathrm{C}$ (shown in Figure 9), the isosteric heats of adsorption were determined by evaluating the slope of a plot of $\ln (P)$ vs. $(1 / T)$ at several coverages. The plots of 

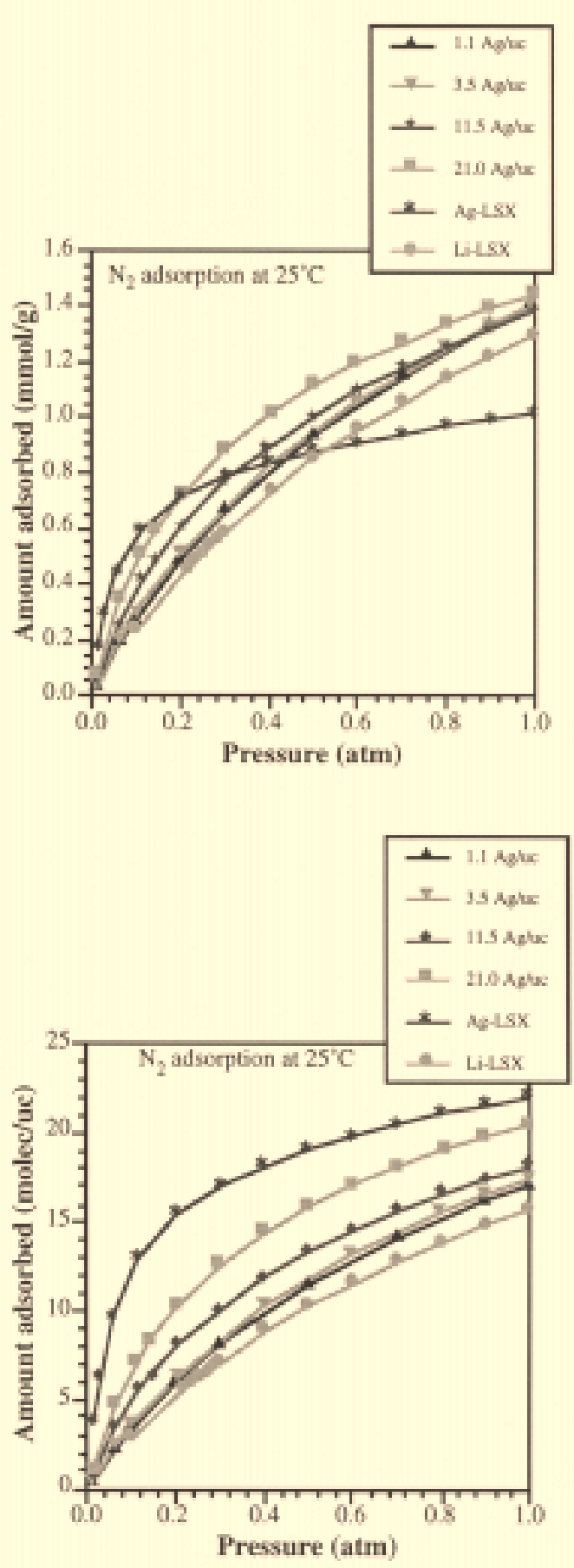

Figure 8. Equilibrium isotherms, measured at $25^{\circ} \mathrm{C}$, for adsorption of $\mathrm{N}_{2}$ on various $\mathrm{Li}_{\mathrm{x}} \mathrm{Ag}_{\mathrm{y}}-\mathrm{X}-1.0 \mathrm{ze}$ olites.

The amount adsorbed is given in molec/U C. This shows that the addition of increasing amounts of $\mathrm{Ag}$ results in a change in the general aspect of isotherm toward that of the near fully $\mathrm{Ag}^{+}$-exchange material.

$\operatorname{In}\left(P_{\mathrm{N}_{2}}\right)$ vs. $(1 / T)$ at several coverages for $L i_{94.5} \mathrm{Na}_{1.5}-L S X$ (top) and $\mathrm{Li}_{94.2} \mathrm{~A} \mathrm{~g}_{1.1} \mathrm{Na}_{0.7}-\mathrm{LSX}$ (bottom) are shown in $\mathrm{Fig}$ ure 10. The isosteric heats of adsorption at different cover-

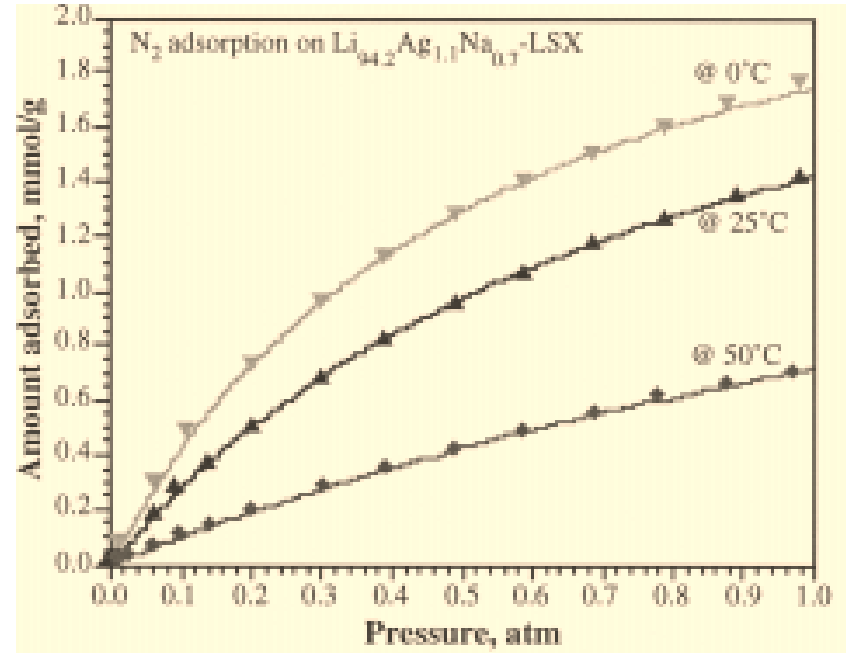

Figure 9. Equilibrium adsorption isotherms, measured at $0^{\circ} \mathrm{C}, 25^{\circ} \mathrm{C}$, and $50^{\circ} \mathrm{C}$, for $\mathrm{N}_{2}$ adsorption on $\mathrm{Li}_{94.2} \mathrm{Ag}_{1.1} \mathrm{Na}_{0.7}$ - LSX zeolite after vacuum dehydration at $450^{\circ} \mathrm{C}$.

ages were calculated for each of these materials and are shown in Figure 11. The plots are shown as the heat of adsorption (in $\mathrm{kcal} / \mathrm{mol}$ ) vs. coverage in molecules of adsorbate per cavity [based on 5.7 cavities per unit cell (Breck, 1984)]. From the plots of the heats of nitrogen adsorption, one can see that the isosteric heat of adsorption for $\mathrm{N}_{2}$ on $\mathrm{Li}_{94.2} \mathrm{~A} \mathrm{~g}_{1.1} \mathrm{Na}_{0.7}-\mathrm{LSX}$ is quite high $(\approx 8 \mathrm{kcal} / \mathrm{mol})$ at low coverages, but immediately drops sharply to become nearly horizontal. This is very similar to that of the near fully exchanged Ag-LSX and indicates the presence of local sites where the $\mathrm{N}_{2}$ is preferentially sorbed more strongly than at other sites within the intracrystalline volume. The heat of adsorption becomes horizontal with adsorption of approximately one $\mathrm{N}_{2}$ molecule per cavity. A comparison with the same plot of the isosteric heat of adsorption for $\mathrm{N}_{2}$ on for $L \mathrm{i}_{94.5} \mathrm{Na}_{1.5}$-LSX zeolite, which is essentially horizontal, shows that the energetic heterogeneity of the $L i_{94.2} \mathrm{Ag}_{1.1} \mathrm{Na}_{0.7}-\mathrm{LSX}$ zeolite is due entirely to the incorporation of the approximately one A g per unit cell. The approximately constant heat of adsorption with increasing coverage for the $\mathrm{Li}_{94.5} \mathrm{Na}_{1.5}-\mathrm{LSX}$ is consistent with previously reported results (B ajusz and Goodwin, 1997), and likely indicates an energetically homogeneous surface.

\section{Structural E ffects on Adsorption}

The adsorbate-zeolite interactions correspond to those between the adsorbing gas and the surface oxygen and charge compensating cations. In faujasite zeolites, the cations in the beta cages and the double 6-ring (hexagonal prism) are sterically inaccessible to nitrogen, and so only the supercage (SII, $\mathrm{SII}^{*}$, and $\mathrm{SIII}$ ) cations interact with the gases of interest in air separation $\left(\mathrm{N}_{2}, \mathrm{O}_{2}\right.$, and $\left.\mathrm{Ar}\right)$. H owever, the electric field around these supercage cations is partially shielded by the surrounding oxygen atoms. Because of this shielding, the electrostatic and induction interactions are expected to be lower than those of an isolated ion. Further, dispersion forces 

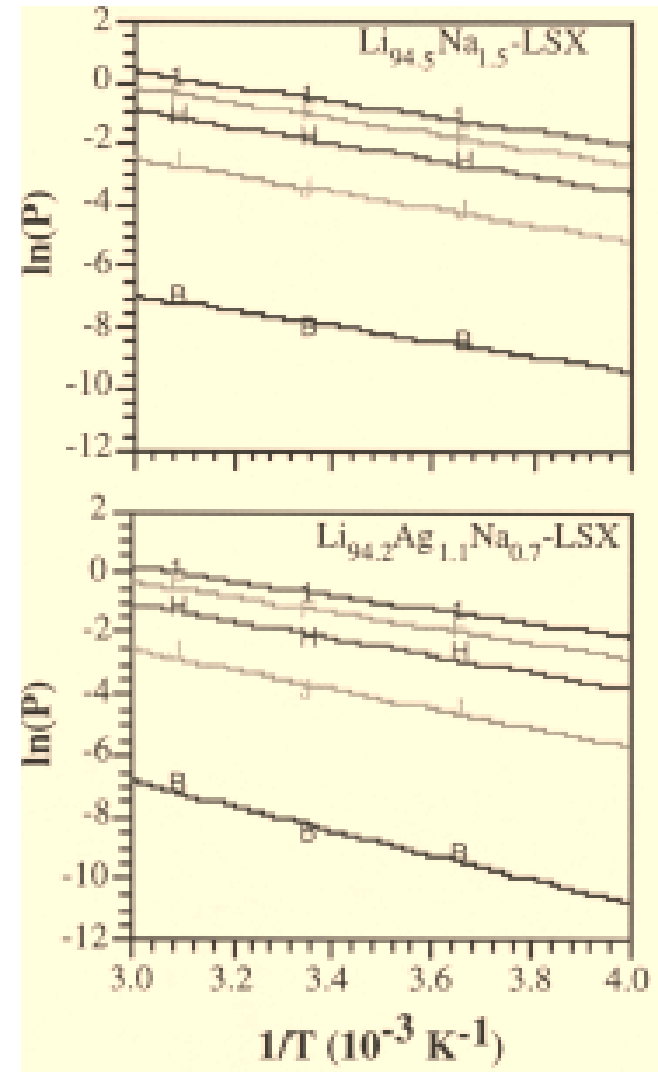

Figure 10. Plots of $\ln (P)$ vs. $\boldsymbol{V} T$ at different coverages for $\mathrm{Li}_{94.5} \mathrm{Na}_{1.5}-\mathrm{LSX}$ (top) and $\mathrm{Li}_{94.2} \mathrm{Ag}_{1.1}$ $\mathrm{Na}_{0.7}$ - LSX (bottom).

acting on the molecule will be higher since adsorbate molecules also interact with oxygen atoms of the zeolite.

From the analysis of the structural data and the resulting effects on the adsorption of nitrogen for the near fully $\mathrm{Ag}^{+}$-

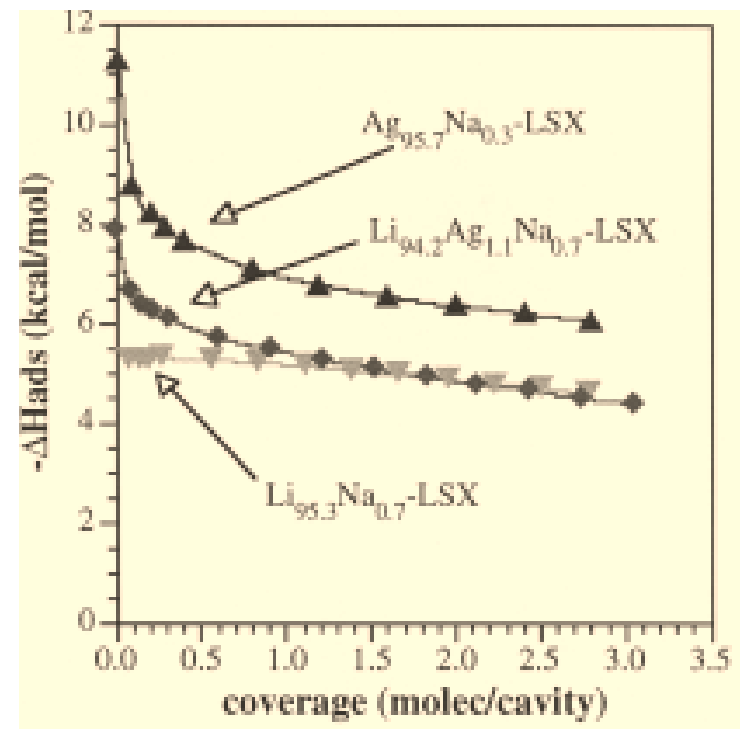

Figure 11. Isosteric heat of adsorption of $N_{2}$ on $\mathrm{Li}_{94.5} \mathrm{Na}_{1.5}-\mathrm{LSX}$ and $\mathrm{Li}_{94.2} \mathrm{Ag}_{1.1} \mathrm{Na}_{0.7}-\mathrm{LSX}$. exchanged LSX (Hutson et al., 2000), one can make inferences of what are the similar effects for mixed Li,A g-LSX. We mentioned earlier that lithium cations located in SII locations do not interact with atmospheric gases because of the short distance, and resulting shielding, to the framework oxygen. Similarly, silver cations in the SII locations, have little effect on the adsorptive properties, again, because of the shielding provided by framework oxygen $(\mathrm{Ag}-\mathrm{Y}$ zeolites have very low $\mathrm{N}_{2}$ adsorptive capacity despite having a full occupancy of SII). However, silver in SII*, are very active (H utson et al., 2000). This helps to explain the increase in the adsorptive capacity of $\mathrm{Li}_{94.2} \mathrm{Ag}_{1.1} \mathrm{Na}_{0.7}-\mathrm{LSX}$ after vacuum dehydration at $450^{\circ} \mathrm{C}$ over that of both the $\mathrm{Li}_{94.2} \mathrm{~A} \mathrm{~g}_{1.1} \mathrm{Na}_{0.7}-\mathrm{LSX}$ after vacuum dehydration at $350^{\circ} \mathrm{C}$ and the $L i_{94.5} \mathrm{Na}_{1.5}-\mathrm{LSX}$. From the structural determinations, only the $\mathrm{Li}_{94.2} \mathrm{Ag}_{1.1} \mathrm{Na}_{0.7}-\mathrm{LSX}$ zeolite contain silver in the $\mathrm{SII}$ * location, after vacuum dehydration at $450^{\circ} \mathrm{C}$. This is supported by the fact that this is the only one of these two samples that showed the enhancement in adsorptive capacity over the near fully $\mathrm{Li}^{+}$-exchanged LSX sample. The same sample, vacuum dehydrated at $350^{\circ} \mathrm{C}$, did not show an enhancement in the adsorptive capacity, because the silver is located in the inaccessible SII' location.

This boost in the adsorption capacity is a result of an increase in the number of $\mathrm{SII}$ * cations. This increase in $\mathrm{SII} *$ cations is a result of thermally induced silver migration from the SII' location. This thermally induced silver migration is likely the result of a partial breakdown of the framework from autoreduction of silver with framework oxygen, as shown in Eq. 2 (H utson et al., 2000):

$$
2\left(\mathrm{Ag}^{+}-\mathrm{Z}-\mathrm{O}^{-}\right) \rightarrow 2 \mathrm{Ag}^{0}+\left(\frac{1}{2}\right) \mathrm{O}_{2}+\mathrm{Z}-\mathrm{O}^{-}+\mathrm{Z}^{+}
$$

The breakdown is not significant enough to destroy the crystallinity of the zeolite, and it is random enough to prevent its detection using $X$-ray or neutron diffraction. However, the breakdown likely creates an energetically unfavorable environment for the silver. As a result, silver in the SII' then moves to the SII or SII* location. Repulsive forces (probably from silver in the SII' location) then push the $\mathrm{Ag}$ into the adsorbate accessible SII* supercage position. The presence of this supercage cation (at the SII* site) results in an adsorptive surface that is energetic heterogeneous.

\section{Acknowledgments}

This work was supported by the U.S. Department of E nergy under Grant DE-FG 26-98FT40115. Neutron activation analyses (NAA) were conducted in the Ford Nuclear R eactor of the Phoenix M emorial Laboratory at the U niversity of Michigan. Leah $M$ inc of the Michigan Memorial Phoenix Project coordinated the analyses. We thank Dr. Frances $Y$ ang for performing the ICP-M S analyses. We acknowledge the support of the National Institute of Standards and Technology, U.S. D epartment of Commerce, for providing the neutron research facilities used in this work and a travel grant for one of the authors (N.D.H.). Drs. Barbara Reisner and Brian Toby, of the NIST Center for Neutron R esearch, were particularly helpful in setting up the experiments and in the use of the GSA S suite. We thank Stefan Zajic, a visiting undergraduate student from the U niversity of Pennsylvania, for help in the synthesis of the Ag- and mixed Li,A gzeolites. 


\section{Literature Cited}

Bajusz, I. G., and J. G. Goodwin, "N $\mathrm{N}_{2}$ Adsorption in LiX Zeolite: I sotopic Transient A nalysis," L angmuir, 13, 6550 (1997).

Barrer, R. M., Zeolites and Clay Minerals as Sorbents and Molecular Sieves, A cademic Press, London (1978).

Breck, D. W. Z Zeolite Molecular Sieves, K rieger, M alabar, FL (1984).

Chao, C. C., "Process for Separating N itrogen from M ixtures Thereof with Less Polar Substances," U .S. Patent N o. 4,859,217 (1989).

Chao, C. C., J. D. Sherman, J. T. Mullhaupt, and C. M. Bolinger "M ixed Ion-Exchanged Zeolites and Processes for the $U$ se Thereof in Gas Separations," U .S. Patent N o. 5,174,979 (1992).

Chen, N., and R. T. Y ang, "A n Ab Initio M olecular Orbital Study of Adsorption of Oxygen, Nitrogen and Ethylene on Silver-Zeolite and Silver H alides," Ind. Eng. Chem. Res., 35, 4020 (1996).

Coe, C. G., J. F. Kirner, R. Pierantozzi, and T. R. White, "Nitrogen A dsorption with a $\mathrm{Ca}$ and/or Sr Exchanged Z eolite," U .S. Patent NO. $5,152,813$ (1992).

Coe, C. G., Access in Nanoporous Materials, T. J. Pinnavaia and M. F. Thorpe, eds., Plenum Press, N ew Y ork, p. 213 (1995).

Feuerstein, M., and R. F. Lobo, "Characterization of Li Cations in Zeolite LiX by Solid-State NMR Spectroscopy and Neutron Diffraction," Chem. Mater., 10, 2197 (1998).

Finger, L. W., D. E. Cox, and A. P. J ephcoat, "Correction for Powder D iffraction Peak A symmetry D ue to A xial Divergence," J. Appl. Crystallogr., 27, 892 (1994).

Fitch, F. R., M. Bulow, and A. F. Ojo, "A dsorptive Separation of Nitrogen and Other Gases," U .S. Patent N o. 5,464,467 (1995).

Freeman, C. M., C. R. A. Catlow, J. M. Thomas, and S. Brode, "Computing the L ocation and E nergetics of O rganic M oelcules in Microporous Adsorbents and Catalysts: A Hybrid Approach A pplied to Isomeric Butenes in a Model Zeolite," Chem. Phys. L ett., 186, 137 (1991)

Habgood, H. W., "A dsorptive and G as Chromatographic Properties of V arious Cationic Forms of Zeolite X," Can. J. Chem., 42, 2340 (1964).

Huang, Y., "Adsorption in AgX and AgY Zeolites by Carbon M onoxide and O ther Simple M olecules," J. Catalysis, 32, 482 (1974).
Hutson, N. D., S. U. R ege, and R. T. Y ang, "M ixed Cation Zeolites: $\mathrm{Li}_{\mathrm{x}} \mathrm{A} \mathrm{g}_{\mathrm{y}} \mathrm{X}$ $\mathrm{X}$ as a Superior A dsorbent for A ir Separation," AIChE J., 45, 724 (1999).

H utson, N. D., B. A. R eisner, R. T. Y ang, and B. H. Toby, "Silver I on-Exchanged Zeolites $Y, X$, and Low Silica $X$ : O bservations of Thermally Induced Cation/Cluster Migration and the Resulting Effects on the Equilibrium A dsorption of Nitrogen," Chem. Mater., (2000).

Knaebel, K. S., and A. Kandybin, "Pressure Swing A dsorption System to Purify Oxygen," U .S. Patent N o. 5,226,933 (1993).

Larson, A. C., and R. B. van Dreele, GSAS: G eneral Structure A nalysis System Manual, L os A lamos R eport LA U R 86-748, L os A lamos National Laboratory, Los Alamos, NM (1986).

Le Bail, A., H. Duroy, and J. L. Fourquet, "Ab Initio Structure Determination of $\mathrm{LiSbW}_{6}$ by $\mathrm{X}-\mathrm{R}$ ay Powder Diffraction," M ater. Res. Bull., 23, 447 (1988).

M cK ee, D. W., "Separation of an Oxygen-Nitrogen M ixture," U .S. Patent N o. 3,140,933 (1964).

R ege, S. U ., and R. T. Y ang, "Limits for A ir Separation by A dsorption with LiX Zeolite," Ind. Eng. Chem. Res., 36, 5358 (1997).

R ietveld, H. M ., "Line Profiles of N eutron Powder-D iffraction Peaks for Structure R efinement," Acta Crystallogr., 22, 151 (1967).

Sun, T., and K. Seff, "Silver Clusters and Chemistry in Zeolites," Chem. Rev., 94, 857 (1994).

$\mathrm{Y}$ ang, R. T., G as Separation by Adsorption Processes, Imperial College Press, London, and World Scientific, River Edge, NJ (1997) (reprinted from Butterworth, Boston, 1987).

Y ang, R. T., Y. D. Chen, J. D. Peck, and N. Chen, "Zeolites Containing $M$ ixed Cations for A ir Separation by Weak Chemisorption-A ssisted Adsorption," Ind. Eng. Chem. Res., 35, 3093 (1996).

Y ang, R. T., and N. D. H utson, "L ithium Based Z eolites Containing Silver and Copper and U se Thereof for Selective A dsorption,"U .S. Patent Pending, U. S. Patent Office N o. 60/114, 371 (1999).

Manuscript received Feb. 24, 2000, and revision received M ay 15, 2000. 